\title{
Razón y fe en Clemente de Alejandría
}

\author{
Marcelo Merino Rodríguez. \\ FACULTAD DE TEOLOGÍA \\ UNIVERSIDAD DE NAVARRA
}

\section{Los antecedentes}

La perspectiva geográfica e histórica que vivió el maestro cristiano de Alejandría hace de él un testimonio privilegiado de las relaciones entre la razón sistematizada (filosofía) y la fe cristiana. Él provenía de ese mundo que había comenzado con los presocráticos y había alcanzado la cima con la especulación de Platón y Aristóteles, y más allá no parecía posible continuar. Habían examinado todos los problemas a fondo, sistemáticamente ordenados en una conexión lógica de ideas, en un sistema. Pero aunque parezca extraño, el problema de la felicidad del hombre, que es tanto como decir el problema del fin, del que la investigación racional había iniciado unos sencillos gestos, permanecía incierto, privado de una respuesta satisfactoria. El problema moral, en su verdadero sentido, no estaba resuelto. La incertidumbre sobre la justificación de las sanciones morales y la obligatoriedad de la ley constituían graves incertidumbres.

El hombre insatisfecho, después de Aristóteles, abandona la especulación metafísica para resolver el problema moral. Surgen entonces -como es sabido- las grandes escuelas morales del epicureísmo y del estoicismo, cuyas doctrinas generan no pocos contrastes entre ellas mismas. Así, el epicureísmo, colocando la felicidad en el placer, intentado como atarasia, o equilibrio del espíritu, y como aponía, o equilibro del cuerpo, pretende la felicidad en un sentido negativo. El estoicismo, por su parte, llega hasta el límite del suicidio, cuando la sabiduría está en peligro. Aparece así el escepticismo, el recelo en el poder de la razón para acceder a lo verdadero, y por último, después de las efímeras e ineficaces experiencias del eclecticismo y del probabilismo académico, se vuelve de nuevo a la religión, como la 
única capaz de infundir certeza en el camino humano hacia la felicidad. La tentativa más ardua, en este sentido, vendrá representada por el neoplatonismo, que es fundamentalmente una perspectiva religiosa de la vida.

Es evidente que en un clima de tanta confusión e incertidumbre, podían encontrar su lugar las más diversas religiones, cada una de las cuales pretendía, a su modo, ser la tabla de salvación para el hombre. En el campo del pensamiento, ningún sistema era determinantemente válido, sino que dejaba al sujeto la facultad de optar. Este cruce de opiniones favorecía, naturalmente, el surgir de falsos profetas del pensamiento -los sofistas-, que de las más diversas maneras reafirmaban que el «hombre es la medida de todas las cosas». Aparece entonces la oferta gnóstica, una extraña mezcla de doctrinas filosóficas, de antiguos mitos y ritos, que prometía a sus discípulos el conocimiento de los problemas fundamentales que atormentaban el espíritu humano, y en cuya gnosis hacía consistir la salvación.

La aparición del cristianismo en el ambiente helénico encontró unas condiciones favorables, como el profundo sentido religioso y la necesidad extrema de un salvador, pero su gran obstáculo consistía en presentarse como la única religión verdadera, con carácter exclusivo. Así nos lo presenta el conocido discurso de san Pablo en el Areópago de Atenas: Todos se reunieron alrededor del altar «al Dios desconocido», pero el mismo auditorio respondió al predicador cristiano: «Te escucharemos sobre esto en otra ocasión» ${ }^{1}$. Es entonces cuando tiene lugar por primera vez la clara conciencia del delicado problema de las relaciones entre razón y fe. No era posible que los griegos aceptaran al nuevo Logos sin haber examinado antes sus credenciales. Pero precisamente por esta necesidad, surgía el peligro de una contaminación, es decir, el peligro de que los filósofos paganos, habituados a sutilezas de la razón, no advirtieran el carácter peculiar, único, de la fe cristiana, su sobrenaturalidad, su carácter misterioso, que no mistérico. No era una nueva filosofía entre otras la que se les presentaba, aunque rica en temas filosóficos esenciales, sino una religión nueva, o mejor, la religión sencillamente. Los peligros se convirtieron en realidad cuando el gnosticismo trató de asimilar los contenidos de la nueva religión, estrechando el cristianismo en su carácter misterioso y reduciéndola a convertirse en elemento del más peligroso eclecticismo naturalístico.

1 Hch $17,32$. 
Contra semejante atentado no se podía permanecer indiferente. Los cristianos reaccionaron con prontitud, aunque su postura no fue del todo clara, unánime y prudente. Lo que les impidió ver con claridad la posibilidad de unas relaciones pacíficas y bienhechoras entre razón y fe, consistió en identificar la conducta de los paganos con la doctrina de quien ellos se declaraban seguidores. Por otra parte les parecía un empobrecimiento a quienes disponían de la verdad revelada, el mendigar migajas de verdad a la puerta de la filosofía. Aunque admitamos que san Justino y otros veían con buenos ojos la utilización de la filosofía para el creyente, no tuvieron conciencia -nos parece-, al menos explícita, de la importancia de las relaciones entre razón y fe, como de un problema que era urgente resolver. Sería Clemente de Alejandría el primero en advertirlo en toda su crudeza.

Intencionadamente hemos titulado en el frontispicio de estas páginas «Razón y fe» y no «Fides et ratio». En estos primeros siglos del cristianismo Clemente sería el autor prototipo de la primera expresión, mientras que Justino sería el abanderado de la segunda. Dejamos de lado en este momento los sarcasmos de Taciano o de Hermas y también los anatemas de Tertuliano respecto a la capacidad de la razón humana en orden a la salvación del hombre? ${ }^{2}$.

A nuestro entender las dificultades de las relaciones entre razón y fe constituyen un problema previo e independiente, a nivel especulativo, respecto al otro de fe y razón. Antes que la utilidad de la filosofía por parte de un creyente que mira a la razón, se encuentra la cuestión de la utilidad de la razón por parte de un filósofo que mira a la fe. Entonces no es solo un problema de uso, de utilización de la razón, sino sobre todo se trata de un problema de naturaleza, la naturaleza de las relaciones entre razón y fe, cuya solución permite, justificándolo, el uso de la razón misma, sea como camino a la fe o como profundización de la misma y que determina los límites.

Todo lector atento de las obras del Alejandrino, especialmente de los Stromata, podrá afirmar que el problema que nos preocupa fue para Clemente un problema de fondo, que subyace en todo su pensamiento y sin el cual no se comprenderían determinadas posiciones y algunas afirmaciones de nuestro Autor. Pero como sucede con cualquier escritor, su obra literaria es fiel reflejo de una serie de circunstancias que la experiencia de su vida le han marcado. Veamos sucintamente estas circunstancias:

2 Cf. L. Allevi, Ellenismo e Cristianesimo (Milano 1934) 199. 


\section{La biografía de Clemente}

Tito Flavio Clemente llega a Alejandría hacia el 180. Había nacido treinta años antes en Atenas $^{3}$, de padres paganos ${ }^{4}$, a mediados del siglo II, hacia el año 150 de nuestra era cristiana ${ }^{5}$. Aunque algunos de entre los autores antiguos lo creyeron natural de Alejandría, según refiere Eusebio, los críticos modernos se pronuncian por Atenas. La cultura y el estilo literario de Clemente abonan también esta hipótesis: él mismo, en una de sus obras ${ }^{6}$, habla de Alejandría como una ciudad a la que había llegado por vez primera para frecuentar la escuela catequética que allí existía 7 . Probablemente, llegó a Alejandría, ya en su madurez, en tiempos del emperador romano Cómodo [180-192]. El historiador Eusebio asegura que «por este tiempo (Clemente) se ejercitaba en las Escrituras divinas y era célebre en Alejandría» ${ }^{8}$.

Clemente no nació cristiano, sino pagano. Pertenecía a una familia pagana y recibió una primera y esmerada educación también pagana ${ }^{9}$. Él mismo refiere ${ }^{10}$ que fue iniciado en los misterios de la religión pagana y en la filosofía griega, y que sus primeros maestros fueron dos griegos [uno de Jonia y otro de Sicilia], un egipcio, un asirio, un palestinense, y, por último,

3 Epifanio, Panar., 32, 6 (PG 41, 552). Las noticias biográficas que han llegado hasta nosotros son muy escasas e inseguras: las fuentes principales son sus propios escritos y los testimonios del historiador Eusebio de Cesarea y de Epifanio de Salamina. Para más detalles, cf. M. Merino - E. Redondo (eds.), Clemente de Alejandría, El Pedagogo, FuP 5, ( Madrid ${ }^{2} 2009$ ).

4 Cf. Eusebio, Prep. Evang., II, 2, 64 (SC 228, 80). Incluso podría deducirse que sus padres eran de ascendencia romana, como lo sugiere el mismo nombre de Tito Flavio.

5 No existe indicación alguna cierta a este respecto. A. Harnack, Die Chronologie, II (Leipzig 1904) 12, propone el año 145.

6 Cf. Strom., I, 11, 2. Todas las citas de Clemente las hemos sacado de la edión que hemos realizado de sus obras en la Colección Fuentes Patrísticas, de la Editorial Ciudad Nueva en Madrid, entre los años 1994-2008.

7 Sobre este particular, cf. A. LE BOUlluEC, «L'école d'Alexandrie. De quelques aventures d'un concept historiographique» en Alexandrina. Mélanges offerts à C. Mondésert (Paris 1987) 402-417.

8 Eusebio de Cesarea, Hist. Eccl., V, 11, 1 (BAC 349, 302).

9 El helenismo cultural de Clemente es el indicio más seguro de sus antecedentes paganos. Cf. A. МÉHAт, Études sur les Stromates de Clément d'Alexandrie (Paris 1966) 43.

10 Cf. Strom., I, 11, 1-2. 
otro siciliano -Panteno-, que era, a la sazón, el fundador y primer director de la Escuela de Alejandría ${ }^{11}$.

Aunque ignoramos las circunstancias de su conversión ${ }^{12}$, Eusebio dice que hacia el año 190, Panteno -su maestro- ${ }^{13}$ le asocia a la enseñanza en la Escuela Catequética de Alejandría; y durante diez años le sucede en el magisterio y, tal vez, en la dirección de la misma ${ }^{14}$. También sabemos que entre sus oyentes está uno -tal vez el más grande- de los intelectuales cristianos de la primera hora -Orígenes- que más tarde tomará el relevo en la dirección de la Escuela ${ }^{15}$. En el año 202, con motivo de la persecución de Septimio Severo, se clausura la Escuela; Clemente huye a Capadocia y ya no regresará a Alejandría.

También tenemos noticia de una carta que un discípulo suyo -Alejandro, Obispo de Cesarea y, más tarde, de Jerusalén- dirige a la Iglesia de Antioquía, y de la que es portador el mismo Clemente. Incluye también unas palabras de presentación y recomendación, en las que se llama a Clemente makárion presbíteron, expresión que podría interpretarse como

11 Clemente también hace referencia a Panteno en su obra Eclogae Propheticae, 56, 2 y Fragm., 23.

12 Bien pudiera ser que tuviera lugar en la misma ciudad de su nacimiento. Así lo hace suponer la cita anterior (Strom., I, 11, 1-2), en la que se refiere los maestros «realmente felices y merecedores de toda estima» porque le transmitieron la verdadera «gnosis», a la que su alma se adhirió finalmente. Clemente menciona a sus maestros en la fe, y el primero, conocido en Grecia, probablemente fue el que le ayudó a convertirse al cristianismo. E. DE FAYE, Clément d'Alexandrie. Études sur les rapports du Christianisme et de la philosophie grecque au IIe siècle (Paris 1906) 18, supone que la conversión de Clemente tuvo lugar durante alguno de sus viajes.

13 Cf. Eusebio de Cesarea, Hist. Eccl., V, 11, 2 (BAC 349, 302).

14 Cf. Eusebio de Cesarea, Hist. Eccl., VI, 6 (BAC 350, 359). Aunque también San JeRÓNIMO, De vir. ill., 54 (PL 23, 664), hace esta afirmación, no es seguro que Clemente ejerciera la dirección de la escuela. Por otra parte, la Escuela de Alejandría no fue en realidad una institución regular, al menos hasta el momento en que Orígenes fue encargado de la catequesis oficial. La enseñanza que impartían Panteno y Clemente parece que no era «oficial», sino privada e independiente. G. BARDY, «Aux origines de l'école d'Alexandrie» en RSR 27 (1937) 65-90, examina con detalle la falta de precisión en las noticias transmitidas por Eusebio.

15 Cf. Eusebio de Cesarea, Hist. Eccl., VI, 6 (BAC 350, 359). Tampoco es seguro en absoluto que Clemente haya sido propiamente maestro de Orígenes. Cf. M. HornsCHUH, «Das Leben des Origenes und die Entstehung der alexandrinischen Schule», en $Z K G 71$ (1960) 1-25 y 193-214; D. DE SA, «L'École chrétienne d'Alexandrie et ses maîtres Clément et Origène» en Cabiers d'Alexandrie s. II, 4 (1964) 3-19; etc. 
«venerable anciano» o como «bienaventurado sacerdote» ${ }^{16}$. Un pasaje de una de las obras de Clemente ${ }^{17}$ ha dado pie también a la discusión sobre su condición de laico o de sacerdote, extremo éste que la crítica moderna pone en duda.

Finalmente, hacia el año 215-216, otra carta del mismo Alejandro -Obispo de Cesarea-, dirigida a Orígenes, habla de Panteno y de Clemente como "padres bienaventurados que nos han precedido en el camino y con los cuales estaremos dentro de poco» ${ }^{18}$, lo que nos permite suponer con cierto fundamento que Clemente debió de morir antes del año 215.

\section{Personalidad}

El cristianismo de los primeros siglos presenta un amplio catálogo de hombres y mujeres de una acusada personalidad, humana y sobrenatural: también en el orden intelectual. Para G. Bardy, Clemente de Alejandría es la primera figura que se destaca con pleno relieve en la historia de la Iglesia $^{19}$. Por su nacimiento y por su formación, se mueve -sociológicamente- en el ámbito de la alta sociedad y de la alta cultura.

Clemente es un hombre temperamentalmente apasionado, entusiasta y optimista $^{20}$; generoso y capaz de entregarse a un ideal -como el cristianopor el que valga la pena vivir y morir. Es menos fogoso que Tertuliano, por ejemplo; y, desde luego, no tiene un ánimo rebelde y conflictivo; $y$,

16 «Esta carta, queridos hermanos míos -escribe Alejandro-, os la he enviado por me-

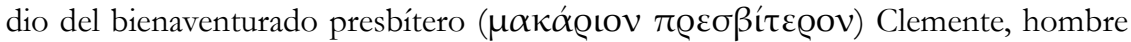
virtuoso y probado, a quien vosotros aprobasteis [...], que ha consolidado y aumentado la Iglesia del Señor» (Eusebio, o. c., VI, 11, 6: BAC 350, 304).

17 Cf. Paed., I, 37, 3. A estos dos testimonios, el de la carta de Alejandro y este pasaje del Pedagogo, sobre el presbiterado de Clemente, hay que añadir la noticia que nos transmite San Jerónimo en el capítulo 38 de su obra De viris illustribus (PL 23, 686s.). Hugo Koch, «War Klemens von Alexandrien Priester?» en ZNW 20 (1921) 43-48, ha estudiado estas tres noticias y concluye que nuestro Clemente no fue presbítero.

18 Eusebio de Cesarea, Hist. Eccl., VI, 14, 8-9: BAC 350, 374. Cf. R. Cadiou, La jeunesse d'Origène. Histoire de l'École d'Alexandrie au début du IIIè siècle (Paris 1935).

19 Cf. J. Champonier, «Naissance de l'humanisme chrétienne», en BulBudé 3 (1947) 5896, especialmente 85-96; G. BARDY, La vie spirituelle d'aprés les Pères des trois premières siècles, vol. 2 (Tournai 1968) 11.

20 Entre otros trabajos, señalamos el de C. SCALFerT, Un éducateur optimiste: Clément d'Alexandrie, Ét 17 (1923) 536-556; etc. 
aunque es un luchador nato, no es un combatiente fanático ${ }^{21}$. Otro rasgo característico de su personalidad es su actitud ante este mundo de aquí abajo: Clemente es un enamorado del mundo y de la vida, y de todo lo bueno y bello que hay en ellos. Esta circunstancia hace de él un hombre muy próximo a la mentalidad y sensibilidad de nuestro tiempo.

Intelectualmente, no es un hombre de talante metafísico, capaz de grandes abstracciones o teorizaciones; no es un pensador muy vigoroso, y mucho menos sistemático, aunque sí es un filósofo penetrante, intuitivo y con grandes dotes de observador ${ }^{22}$. Tampoco destaca por su talento organizador y sistematizador: a menudo carece de un orden y de un método que le lleven a un desarrollo acabado de las ideas. Al meterse en el análisis de un tema, pierde con facilidad la visión de conjunto y cae en la digresión y el detallismo. Claude Mondésert, uno de los mejores conocedores de nuestro autor, lo describe como «un espíritu curioso y abierto, intuitivo y analítico, vivo y brillante, pero incapaz de una exposición metódica y ordenada, sin ser por esto tan incoherente como se ha pretendido» ${ }^{23}$. Clemente tiene un gran sentido del empleo de la imagen, de la comparación, de la alegoría y de los recursos plásticos, que hacen de él un excelente maestro.

En cuanto a su preparación y a su bagaje o equipamiento intelectual, hay que decir que poseía una erudición extraordinaria; eso sí, más vasta que profunda: le es muy familiar la literatura pagana, la cristiana, tanto la gnóstica herética como la ortodoxa, y la judía. Y, por supuesto, conoce perfectamente la Sagrada Escritura. Investigaciones modernas sobre las fuentes de su erudición, han puesto de relieve que Clemente hizo uso a veces de antologías, florilegios y compendios, muy corrientes en su tiempo. Pero, sin duda, no debe exagerarse: la solidez de su erudición descansa en el recurso frecuente a las fuentes originales.

Por último, una breve referencia a su actitud intelectual y a su filiación ideológica: Clemente no está enfeudado en ninguna filosofía concreta o de escuela: lo que él llama filosofía no es el estoicismo, ni el platonismo ni el epicureísmo; ni tampoco el eclecticismo, en el sentido habitual de esta

21 Es un enamorado de la libertad humana, de la propia y de la de los demás. No en balde esta actitud suya le ha merecido, entre algunos estudiosos contemporáneos, el sobrenombre de liberal, en el sentido más noble de la palabra; cf. J. SARIOL, «Clemente de Alejandría, un teólogo liberal» en AnGir 20 (1970/71) 357-316; etc.

22 Cf. M. Merino Rodríguez, «Clemente de Alejandría, un filósofo cristiano», en Scripta Theologica 45/3 (2008) 803-837.

23 C. Mondésert, Clément d'Alexandrie (Paris 1944) 4. 
palabra; aunque se aprecian en él -eso sí- ciertas preferencias por el platonismo medio y el estoicismo. Ciertamente Platón, en especial, es citado por él con muchísima frecuencia. A. de la Barre ${ }^{24}$ ha destacado un rasgo muy interesante de su actitud intelectual: Clemente está convencido de que la sabiduría humana -aunque imperfecta- puede servir para traducir la sabiduría divina. Por eso, fue uno de los grandes entusiastas y pioneros del empeño de armonización entre la Razón y la Fe. Sin duda, su excesivo empeño armonizador le hizo caer en algunas imprecisiones doctrinales.

\section{Circunstancia histórica}

Desde la perspectiva diacrónica, el tiempo histórico que le tocó vivir a Clemente de Alejandría está signado por dos acontecimientos especialmente relevantes. El primero -también cronológicamente- es el encuentro de dos pueblos -Grecia y Roma- y la fusión o integración de dos culturas: la paideia griega y la bumanitas romana. Este encuentro genera una cultura pagana en la que vienen a integrarse también elementos judaicos y orientales. La cultura helenística, que había integrado los cuatro elementos básicos de la paideia griega clásica -el filosófico, el filológico, el poético y el gimnástico- presentaba signos inequívocos de decadencia. La filosofía, desprovista de su empuje creador y de sus altos vuelos metafísicos, vive de la tradición socrático-platónica y aristotélica, fragmentada en numerosas sectas y corrientes diversas. La retórica ha perdido también la fuerza creadora, que nacía en buena parte de la constitución y estilo democráticos de la vida ateniense: suprimida la libertad política, la retórica se había convertido en una elocuencia de escuela con un tecnicismo minuciosamente codificado. La poesía seguía viviendo también de los grandes maestros de la época clásica. En cuanto a la cultura física -la gimnástica- había degenerado en una molicie blandengue, propicia a ciertas aberraciones. En resumen: el formalismo y la tendencia a la síntesis y al eclecticismo pueden considerarse como rasgos definitorios de la paideia ${ }^{25}$ helenística, creadora de un nuevo humanismo -más universalista y más técnico, pero menos creador-, promovido principalmente por las escuelas peripatéticas, estoicas y epicúreas, que reconocen al hombre como «ciudadano del mundo». A estos rasgos hay que añadir, por otra parte, la tendencia a la universalidad y al cosmopolitismo, rasgo que faltaba en cambio en la paideia clásica,

24 Cf. A. DE la Barre, «Clément d'Alexandrie» en DThC 3, 138.

25 Empleamos aquí el término paideia en el sentido amplio de cultura. 
aunque había sido intuido y preconizado ya por algunos sofistas y por Isócrates $^{26}$.

El segundo de los acontecimientos mencionados, más decisivo y determinante que el anterior, es un nuevo encuentro y una segunda integración: esta vez, del cristianismo naciente con la cultura grecorromana. El cristianismo era, esencialmente, una persona -Jesucristo, perfecto Dios y perfecto Hombre- y traía un mensaje de salvación, radicalmente teocéntrico, que suponía una profunda subversión en la concepción de la vida y de la escala de valores del mundo pagano y comportaba además un peculiar estilo de vida: en esto radicaba su originalidad y su fuerza. Pero el cristianismo no era propiamente creador de una cultura. En realidad -como sugiere Marrou- ${ }^{27}$ no crea civilizaciones; lo que hace es salvarlas; las asume, las informa, las modela, conformándolas a su propia perspectiva; suprime o corrige lo que es inconciliable con el espíritu del Evangelio; incorpora y conserva lo que es bueno y potencia y eleva lo que aún no ha llegado a su acabamiento y perfección.

Desde una perspectiva sincrónica -geográfico-cultural- la circunstancia de Clemente puede concretarse, aparte de aquella en que le colocó su nacimiento y educación, en un nombre y en una ciudad: Alejandría [331 a. de C.]. En tiempos de Clemente, la ciudad del delta del río Nilo era el gran centro cultural del helenismo: gozaba de una situación geográfica privilegiada, como cruce de las rutas de Oriente y Occidente; era una ciudad rica, suntuosa, refinada; capital del cosmopolitismo social, político y religioso; lugar de concurrencia e intercambio de gentes de todas las razas; allí podían encontrarse fieles de todas las religiones, sacerdotes de todos los cultos, maestros y cultivadores de todas las ramas del saber; filósofos, poetas y científicos, procedentes de todo el Imperio, conviven en Alejandría a la sombra de sus célebres instituciones culturales y científicas: la Biblioteca y el Museo. En ella se daban cita, entremezclándose y fundiéndose, culturas tan diversas como la judía, la grecorromana -con su potente elemento racional, literario e institucional-, la oriental -con sus elementos míticos y mistagógicos- y la antiquísima y decantada cultura egipcia. Por este tiempo, había ya en Alejandría un potente foco judío -el de la diáspora o de los alejandrinos- de tendencia helenizante, enfrentado al de los palestinenses,

26 Cf. Isócrates, Panegírico, 47ss. Véase también W. JaEger, Cristianismo primitivo y paideia griega, (México - Buenos Aires 1965) 94; F. RodríGuez Adrados, Ilustración y política en la Grecia clásica (Madrid 1966) 377-381.

27 Cf. H.-I. Marrou, Le Pédagogue, vol. I (Paris 1960) 66. 
más localistas y conservadores. También en tiempos cercanos a Clemente había comenzado a constituirse un importante núcleo cristiano, que mantenía cierta rivalidad con el de Roma, y especialmente con el de Antioquía. El cristianismo había penetrado ya de tal modo en las altas esferas de la sociedad alejandrina, que aparecía como el bastión del helenismo: ya no era, a los ojos de los paganos, solamente una religión de iletrados, de esclavos, de artesanos, de la plebe, como pocos años antes ${ }^{28}$. Y para que este abigarrado mapa cultural -filosófico, científico y religioso- quedase completo, también se habían dado cita en Alejandría -ya en el siglo IIlos grandes gnósticos heréticos: Basílides, Valentín y Carpócrates, entre otros, que dejaron allí numerosos e influyentes discípulos ${ }^{29}$.

Pues bien, Clemente recibe su segunda formación -la cristiana- y realiza su obra dentro de este ámbito geográfico-cultural del helenismo, que tiene su centro en la ciudad fundada por Alejandro Magno. En esta ciudad -y en este ambiente- ejerce Clemente su magisterio desde la cátedra de la Escuela de Alejandría, en la que ha substituido a Panteno. Su abigarrado y variopinto auditorio está constituido por los oyentes más variados: mujeres de la alta sociedad, que calzan zapatos de altos tacones y se adornan con perlas y piedras preciosas; hombres afeitados y perfumados; jóvenes ociosos; filósofos que andan en busca de la verdadera sabiduría; rétores, atraídos por la reputación del maestro cristiano; heréticos, ávidos de polémica; cristianos de a pie-simpliciores- que aspiran a elevarse por encima de la simple fe hasta la gnosis.

Nada tiene de extraño que un espíritu amante de la verdad como es el de Clemente, rodeado de ese patrimonio de investigación, de estudio y de ideas, encuentre el bumus perfecto para germinar y dar los mejores frutos en su misma obra literaria y también en los originales de otros autores cristianos. Ciertamente, en lo referente a los escritos clementinos más importantes que han llegado hasta nosotros, el Protréptico, el Pedagogo y los Stromata, dejan entrever en cada una de sus páginas el anhelo por alcanzar

28 Cf. H.-I. Marrou, Le Pédagogue, 64.

29 Especialmente obscuros son los comienzos de la Iglesia en Egipto, que desde el siglo III jugó un papel muy importante en la historia eclesiástica de la Antigüedad. Cf. W. BAUER, Rechtgläubigkeit und Ketzerei im ältesten Christentum (Tübingen 1964) 49-64; E. Dassmann, Kirchengeschichte I. Ausbreitung, Leben und Lebre der Kirche in den ersten drei Jahrbunderten (Stuttgart - Berlin - Köln 1991) 263; C. W. GRIGGs, Early Egyptian Christianity. From its origins to 451 C. E. (Leiden - New York - Köln $\left.{ }^{3} 1993\right)$; J. FERnández SANGRAdor, Los orígenes de la comunidad cristiana de Alejandría (Salamanca 1994). 
la verdad, sirviéndose de todo lo que se encuentra al alcance de su mano: la ciencia humana y la revelación divina. De este sencillo método nacerá el primer tratado teológico y moral de la Patrística, de igual manera que certificará el camino teológico que recorrerán otros autores cristianos para aproximarse al conocimiento de la Verdad divina.

Prescindiendo de algunas observaciones accidentales y de otros aspectos particulares, la intención primera de nuestro Autor, ya convertido en maestro cristiano, parece innegable y él mismo la explicita en un conocido texto del Pedagogo: «El Logos, guía celestial, tomaba el nombre de protréptico al exhortarnos a la salvación; éste es el título específico que recibió el Logos, cuando se encargaba de estimularnos a la conversión... Pero ahora, actuando a la vez como terapeuta y como consejero, sucediéndose a sí mismo, anima al que antes ha convertido... Hemos de otorgarle, por tanto, el único nombre que propiamente le corresponde: el de pedagogo. El mismo Logos es también maestro, pero no lo es todavía. El Logosmaestro tiene la función de exponer y revelar las verdades doctrinales $\rangle^{30}$. En unas líneas un poco más abajo, otro texto de su Pedagogo parece definitivo: «Y es así como el Logos, amigo cabal de los hombres y empeñado en conducirnos progresivamente a la salvación, realiza en nosotros un bello y eficaz programa educativo: primero nos exhorta; luego, nos educa; finalmente, nos enseña $\aleph^{31}$. Sin duda, éste era el proyecto literario de Clemente, pero la vida misma le llevó por otros caminos no previstos.

\section{El fin y los objetivos de la enseñanza clementina}

Bajo esta luz es como se debe ver su actitud tan abierta y bien dispuesta hacia la razón humana. Clemente, al igual que las demás escuelas filosóficas de su tiempo, concibe la especulación al servicio de la vida. El problema que él tiene en el corazón es el problema moral, que para él se identifica en la práctica con el problema religioso. También con esta perspectiva se entiende claramente la misma definición que el Alejandrino confiere a la filosofía: «Yo no llamo filosofía a la estoica, ni a la platónica, ni a la

30 Paed., I, 1, 3-2, 1. Para las cuestiones literarias de este texto, véase nuestra edición del Pedagogo: M. Merino - E. Redondo, Clemente de Alejandría, El Pedagogo, especialmente las pp. $24-27$ y $71-75$.

31 Paed., I, 3, 3. Para el problema literario de las obras clementinas, remitimos al lector a nuestra Introducción del primer volumen editado sobre los Stromata: M. Merino Rodríguez, Clemente de Alejandría, Stromata I, Cultura y religión, FuP 7 (Madrid 1996) 12-26. 
epicúrea, ni a la aristotélica, sino a lo que en cada uno de esos sistemas se dice convenientemente, y que enseña a fondo la justicia al mismo tiempo que el saber piadoso; a todo ese conjunto ecléctico denomino filosofía ${ }^{32}$. Pero cuanto [los filósofos] se exceden más de lo debido, extrayéndolo de razonamientos humanos, eso no lo llamaré jamás divino $»^{33}$. Y también: «La filosofía no se encuentra en la geometría, que entraña postulados e hipótesis; ni en la música, que se basa en conjeturas; ni en la astronomía, que está repleta de razonamientos que fluyen y de imágenes físicas; en cambio, [la filosofía] es la ciencia de la verdad y del bien en sí mismo; aquellas otras [ciencias] son distintas del Bien, y tan solo son caminos de acceso al Bien» ${ }^{34}$. Y en el libro segundo de sus Stromata igualmente se puede leer: «Es imposible que una persona sin principios de enseñanza ${ }^{35}$ sea filósofo permaneciendo en la ignorancia, puesto que no posee todavía el concepto de sabiduría, mientras que la filosofía es la aspiración a lo que existe en realidad y a los aprendizajes que tienden a ello ${ }^{36}$. Y aún cuando se esté ya ejercitado, según algunos, para practicar el bien, también es necesario esforzarse por conocer cómo nos comportamos y actuamos, para así hacerse uno semejante a $\operatorname{Dios}^{37}$, me refiero al Dios Salvador, dando

32 El eclecticismo del Alejandrino, característica de la filosofía del Platonismo Medio, es puesto de manifiesto no solo en este lugar, sino en otros pasajes de los Stromata. $\mathrm{Al}$ respecto, cf. R. P. CASEY, «Clement of Alexandria and the Beginnings of Christian Platonism» en HThR 18 (1925) 95; S. R. C. LiLla, Clement of Alexandria. A Study in Christian Platonism and Gnosticism (Oxford 1971) 51-56; W. E. G. Floyd, Clement of Alexandria's Treatment of the Problem of Evil (Oxford 1971) XIX; A. DessI, «Elementi epicurei in Clemente Alessandrino. Alcune considerazioni» en AtPavia 60 (1982) 402. Sobre el concepto de «filosofía», cf. L. FARINELLI, «Filosofia e Rivelazione in Clemente Alessandrino» en Filosofia e Vita 6 (1965) 222-228.

33 Strom., I, 37, 6.

34 Strom., I, 93, 4.

35 En el pensamiento de Clemente el término $\alpha \dot{\mu} \alpha \theta$ í $\alpha$ no significa solo la incultura, sino principalmente el rechazo de la cultura; por eso aplica dicho término a los teóricos de la ignorancia (cf. Strom., I, 18, 2) y a los que no han tenido acceso a la filosofía, como es el caso presente.

36 El concepto que Clemente tiene de la filosofía es muy diferente al que tenemos nosotros; a él no le interesan ni los sistemas ni la especulación abstracta de los problemas humanos, sino la verdad que atañe al actuar del hombre: L. FArinelLi, Filosofia e rivelazione, p. 23.

37 Esta es la meta de toda la vida terrena del hombre, y una de las ideas más frecuentemente explicitadas por Clemente. 
culto al Dios del universo mediante el Logos, sumo $\operatorname{sacerdote}^{38}$, por el que se pueden ver las realidades bellas y justas conforme a la verdad. La piedad... ${ }^{39}$ es un actuar que sigue y acompaña a Dios ${ }^{40}$.

Todo el pensamiento del Alejandrino se mueve por una preocupación apostólica implícita, pero suficientemente clara para quien lee sus escritos con la debida atención y no es otro que el problema de la salvación. Basta pensar en la preocupación, enteramente vehemente y pasional del Protréptico, que concluye con el siguiente reto: «A vosotros os queda todavía el conquistar finalmente lo más provechoso: el juicio o la gracia. Al menos yo pienso que no es legítimo dudar sobre cuál de esas cosas es mejor; ni tampoco es lícito comparar la vida con la perdición» ${ }^{41}$.

\section{Las dificultades de la razón}

Clemente, antes de defender su «tesis», por así decir, sobre las correspondencias entre razón y fe, trata de superar una serie de dificultades y recelos de sus hermanos de religión, incluso de los más ilustrados. En efecto, algunos de estos a los que el Alejandrino califica, no sin ironía, como «ignorantes timoratos» ${ }^{42}$, sostenían que «es necesario ocuparse de lo más imprescindible, o sea, de lo que contiene la fe, y descuidar igualmente las cosas externas y superfluas, que nos fatigan inútilmente y nos

38 Se trata de un título cristológico muy querido por los escritores cristianos de la antigüedad, cf. A. Orbe, La Unción del Verbo. Estudios Valentinianos, vol. III (Analecta Gregoriana 113; Romae 1961) 543-562. Es un título que manifiesta la función de Cristo de llevar los hombres al Padre, para alcanzar la identificación divina.

39 Probable laguna del manuscrito. Sobre el concepto de «piedad», cf. J. IBÁÑEZ F. Mendoza, «El tema literario de la "Eusebeia" en Clemente Alejandrino», en TEsp 17 (1973) 233-235.

40 Strom., II, 45, 6.

41 Protr., 123, 2.

42 Parece tratarse de una alusión indirecta a las opiniones de Taciano y Tertuliano, entre otros, sobre el origen de la filosofía; cf. P. СAмELot, Foi et Gnose. Introduction à l'étude de la connaissance mystique chez Clément d'Alexandrie (Paris 1945) 17-18; W. BIERBAUM, «Geschichte als Paidagogia Theou. Die Heilsgeschichtslehre des Klemens von Alexandrien» en MThZ 5 (1954) 249; A. OrBE, En los albores de la exégesis Iohannea (Ioh. I, 3). Estudios Valentinianos, vol. V (Analecta Gregoriana 65 ; Romae 1955) 181; F. DraczKowski, «Qua paideia Clemens Alexandrinus imbutus appareat in animadvertenda falsa gnosi» en $S A C 2$ (1980), 57; A. MéHAT, «La La philosophie, troisième testament? La pensée grecque et la foi selon Clément d'Alexandrie» en LumVi 161/32 (1983) 16-18. 
ocupan el tiempo sin aportar nada al objetivo final» ${ }^{43}$. Y como si eso no fuera suficiente, otros sostenían que «la filosofía es mala, porque se ha introducido en la vida de los hombres para su perdición por un malvado inventor» ${ }^{44}$. También había quienes mantenían que «la filosofía perjudica por sí misma a la vida» ${ }^{45}$, o que pone en peligro la $\mathrm{fe}^{46}$. Incluso no faltaban quienes reprochaban a la razón humana ser la culpable del nacimiento de distintas herejías.

Clemente tendrá una respuesta para todos, meditada e incluso vivamente polémica. Así advierte: «En primer lugar, para suponer que la filosofía es inútil, al menos sería útil establecer la afirmación de su inutilidad» ${ }^{47}$. Es decir, para probar la inutilidad, e incluso maldad, de la filosofía ya hay que filosofar. En segundo lugar, tampoco se puede condenar a los griegos simplemente por la mención de las doctrinas que en ellos se contienen, sin penetrar a la vez hasta el fondo y descubrir su inteligencia ${ }^{48}$. En esta misma línea argumentativa del Alejandrino hay que entender estas otras palabras suyas: «La demostración más perfecta se manifiesta con el conocimiento de lo refutado» ${ }^{49}$. Y se podrían enlazar una serie de textos alejandrinos que rebaten la inutilidad, culpabilidad o el origen malintencionado de la capacidad del raciocinio humano; todo el capítulo segundo de su primer libro de los Stromata ofrece una serie de argumentaciones al respecto. Pero no nos resistimos a leer unas palabras en las que Clemente subraya con fuerza la importancia de la razón: «El razonamiento [que procede] de las demostraciones infunde una fe segura ${ }^{50}$ en el alma del que

43 Strom., I, 18, 2.

44 Strom., I, 18, 3. Sobre el origen y estima de la filosofía en el Alejandrino, cf. G. PINI, Clemente Alessandrino. Stromati. Note di vera filosofia, (Roma 1985) 81-82, nota 91, con abundante bibliografía al respecto.

45 Strom., I, 20, 1.

46 Cf. Strom., I, 20, 2.

47 Para demostrar la inutilidad de la filosofía es necesario filosofar, decía Aristóteles en su Protréptico, fragm. 51 (Rose 56s). Cf. E. Molland, «Clement of Alexandria on the Origin of Greek Philosophy» en ID., Opuscula patristica (Oslo 1970) 118, nota 6, quien recuerda el pensamiento de Pascal: Se moquer de la philosophie, c'est vraiment philosopher.

Strom., I, 19, 1-2.

Strom., I, 19, 3.

Cf. H. A. Wolfson, La filosofia dei Padri della Chiesa, vol. I, trad. ital. (Brescia 1978) 117. En el pensamiento de Clemente, la fe es anterior a la gnosis, pero ésta última es superior a la fe en el sentido de que facilita las razones para creer, cf. P. CAMELOT, «Clément d'Alexandrie et l'utilisation de la philosophie grecque» en RechSR 21 (1931) 
lo sigue, de tal modo que no permite suponer que lo demostrado sea de otra manera; además impide que [los sofistas] se insinúen junto a nosotros para hacernos caen $\rangle^{51}$. Esta «fe segura», literalmente «fe exacta», no alude a la fe de la revelación cristiana, sino a la fe científica.

Es cierto que los profetas y los apóstoles no tuvieron necesidad de la filosofía, pero no es menos cierto, responde Clemente, que «también el pensamiento del Espíritu profético y didáctico, hablando en términos obscuros, puesto que no pertenece a todos el descubrirlo y entenderlo, reclama los métodos didácticos para hacerlo evidente» ${ }^{52}$. Por otra parte, la filosofía no es necesariamente la fuente de las herejías, sino solo cuando está inspirada por el orgullo de la razón y de la presunción. Sobre la herejía dirá en el libro séptimo de sus Stromata: «Cuando tenemos delante dos frutos, uno auténtico y maduro, y otro hecho de cera y muy parecido, no es necesario abstenerse de los dos porque se parezcan, sino que hay que saber distinguir con visión comprensiva y a la vez con el razonamiento más perentorio el fruto aparente del verdadero... También las hierbas nacen junto a las verduras de cultivo; ¿acaso por eso los agricultores renuncian al cultivo de las hortalizas? $\rangle^{53}$.

\section{La razón como medio universal de salvación}

Pero lo más característico del pensamiento del Alejandrino es que no se limita a defender el uso y la función de la razón en orden a la fe. Después de poner en evidencia la inconsistencia de algunas dificultades y el inútil temor de mucha gente timorata que tiene miedo al riesgo de la propia fe en su contacto con la razón humana, Clemente pasa al ataque y afronta el problema de la relación entre ambas, dando una profunda justificación de la misma verdad cristiana.

El presupuesto en el que se fundamenta la reflexión del maestro Alejandrino es la voluntad salvífica de Dios. Con otras palabras, la salvación eterna como fin último del existir humano. Esta es la verdadera perspectiva en la que sitúa el problema de las relaciones entre razón y fe.

552-558; J. DaniéLou, Message évangélique et culture hellenistique aux IIe et IIIe siècles (Bibliotèque de Théologie; Tournai 1958-1961) 295-296, trad. esp. Cristiandad, (Madrid 2002).

51 Strom., I, 33, 2.

52 Strom., I, 45, 1.

53 Strom., VII, 91, 2.6. 
Clemente sabe muy bien, por la lectura de la Sagrada Escritura, que Dios quiere que todos se salven. La consecuencia inevitable de este principio es que Dios ha tenido que dar a todos los hombres los medios necesarios para alcanzar esa salvación. Desde esta atalaya se ve toda la amplitud que nuestro Autor concede a la verdad de un Dios providente y por qué él no tiene en consideración las escuelas filosóficas que no han reconocido la existencia de la Providencia: «Según la tradición divina ${ }^{54}$, la Providencia se mantiene en pie y consolida por la filosofía, y quitada ésta, la economía ${ }^{55}$ salvífica parece un mito ${ }^{56}$. Sería un acto de clara iniquidad -prosigue el Alejandrino- que los que han partido antes de la venida del Señor, tuvieran salvación o castigo sin haber sido evangelizados, y, por ello, sin tener responsabilidad alguna en creer o no $\operatorname{creer}^{57}$. En efecto, no es justo que esos sean condenados sin juicio, y que solo gocen de la justicia divina los que han existido después de la venida [de Cristo] $\rangle^{58}$. Es decir, Dios no sería justo si no hubiera dado a todos la posibilidad de salvarse, y hubiera querido a la vez que todos los hombres se salvaran.

De estas palabras surge la conclusión lógica de Clemente: Dios ha dado históricamente a los judíos la ley, y a los griegos la razón, como medio de garantía salvífica. Para el Alejandrino esta verdad está fuera de toda discusión: «Merecidamente, pues, [se ha concedido] a los judíos la ley y a los griegos la filosofía, hasta la venida. Desde esta perspectiva existe la llamada universal: que el único Dios que es el solo Dios de los dos pueblos, griegos y bárbaros [cristianos], o mejor de todo el género humano, mediante el único Señor lo reúne a la vez en un pueblo singular ${ }^{59}$ de justicia» ${ }^{60}$. Sin duda, Clemente afirma que la razón sistematizada, la filosofía, es el «testamento» que Dios ha concedido a los griegos ${ }^{61} \mathrm{y}$ ha tratado de esclarecer esta «función» del pensamiento concedido a los

54 J. DaniéLou, «La tradition selon Clément d'Alexandrie», en AugR 12 (1972) 10-11, ha estudiado la diferencia entre tradición divina y tradición humana. E. MOLLAND, The origin, 118, considera el cristianismo de Clemente como una filosofía.

55 La «economía salvífica» es obra primordial de la Providencia. Cf. A. MéHat, Étude, 309-310; A. Brontesi, La soteria in Clemente Alessandrino (Roma 1972) 340ss.

56 Strom., I, 52, 2.

57 Cf. Strom., II, 26, 3.

58 Strom., VI, 48, 4-5.

59 Ex. 19, 5.

60 Strom., VI, 159, 9.

61 Cf. Strom., VI, 67, 1. 
griegos, como medio de salvación, sea antes de la venida de Cristo como después.

Es verdad que en Clemente, como en otros apologistas cristianos, despliega el tema de la dependencia de la filosofía respecto de la Revelación, como si los filósofos fueran unos plagiarios de Moisés y de los profetas, desprovistos de cualquier originalidad, pero esta perspectiva hay que enmarcarla en un cuadro diferente, como es el de la antigüedad de la religión cristiana, y que no constituye el fundamento de toda su concepción de las relaciones entre razón y fe. Más bien habría que situar esta tesis como un complemento que no desprecia, sino que marca con trazos más claros y que sirve mejor para justificar su posición frente a la razón humana.

Unas palabras explícitas del Alejandrino reconocen como necesarias dos verdades para el pagano en orden a la salvación: la existencia de Dios y que este Dios es remunerador. Estas son sus palabras explícitas: «Por lo menos aquellas doctrinas filosóficas que proclaman un orden providencial y la recompensa de la vida bienaventurada y al contrario, el castigo de la vida de condenación, hablan compendiosamente de la teología ${ }^{62}$. Naturalmente, sin la revelación -proseguirá Clemente- el pagano no podrá conocer la existencia de la Trinidad y, por lo mismo, la del Hijo de Dios; por tanto, el conocimiento pagano de la existencia de Dios será incompleto y, si se quiere, superficial, aunque suficiente en orden a la salvación. Los paganos han conocido a Dios, y lo han conocido no por la fe, sino por la razón. Y si el conocimiento de Dios es necesario para la salvación, entonces quiere decir que la razón, al menos en la economía anterior a la venida de Cristo, podía bastarse a sí misma. Dios no exigía más.

El pensamiento de Clemente en este orden no es siempre claro y coherente; pero, quizás, más en apariencia que en sustancia. No duda en afirmar que los paganos conocían a Dios con las siguientes palabras: «Existía, pues, también entre los paganos un vago conocimiento de Dios» ${ }^{63}$. En otro libro de sus Stromata afirma: «Los filósofos griegos más críticos veían a Dios mediante reflejo y transparencia. Tales son, a causa de su debilidad, las representaciones de la verdad: como una imagen que se observa en las aguas o a través de cuerpos transparentes y diáfanos» ${ }^{64}$. En otras

62 Strom., VI, 123, 2.

63 Strom., VI, 64, 6.

64 Strom., I, 94, 7. Para Clemente hay dos formas de acceder a la verdad: una indirecta, que puede captar el reflejo de la verdad, pero no puede penetrar en su realidad; ésta 
ocasiones parece afirmar lo contrario: «Puesto que Dios es indemostrable, no es objeto de ciencia» ${ }^{65}$; también nuestro Autor deja escrito que Dios es un ser «difícil de captar y capturar, porque siempre se aleja y se retira ante quien lo acecha» ${ }^{66}$; finalmente, para no alargar los textos clementinos, en línea con el neoplatonismo, sostiene que de Dios es más fácil saber lo que no es, que lo que es ${ }^{67}$, «y si lo nombramos alguna vez, no es sino de manera impropia, pues al llamarle Uno, Bien, Inteligencia o el propio Ser ${ }^{68}$, Padre, Dios, Demiurgo o Señor, no lo decimos como quien profiere su nombre, sino que por la dificultad nos servimos de nombres hermosos, para que la mente, sin divagar en otras cosas, se apoye en ellos» ${ }^{69}$.

Hay que excluir toda contradicción en las divergentes opiniones de Clemente sobre el conocimiento racional de Dios. Para él es pacífico el que los paganos han conocido a Dios, pero no es menos verdad que Dios es difícil de comprender; la dificultad reside en la conciliación de esos dos extremos. Cuando Clemente sostiene que Dios no puede ser conocido, se refiere a la esencia de Dios, a la noción de Dios, que al cristiano le viene por la fe revelada. Aparece aquí, en el Alejandrino, la aparente antinomia

es de la que aquí habla: L. FARINELLI, Filosofia e rivelazione, 28. Existe otra forma de conocer la verdad, de penetrar directamente en su realidad; pero para ello es necesario un sentido especial que viene solo a través de la fe. Cf. R. MorTLEY, «The Mirror and I Cor. 13, 12 in the Epistemology of Clement of Alexandria» en VigChr 30 (1970) 115-116; L. Gallinari, La problematica, 89-91.

65 Strom., IV, 156, 1. Sobre el carácter infalible de Dios, cf. L. Farinelli, Filosofia, 28;

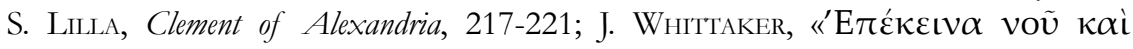
oúoí $\alpha \varsigma »$ en VigChr 23 (1966) 98-99; J. MoIngt, La gnose, 546; E. DE FaYe, Clément d'Alexandrie, 230-247; E. F. Osborn, The Philosophy, 38.

${ }_{66}$ Strom., II, 5, 3. Dios trasciende de tal forma al mundo sensible que ni siquiera el lenguaje humano es suficientemente adecuado para expresar la naturaleza divina; cf. W. E. G. FLOYD, The problem of evil, 6-7.

67 Cf. Strom., V, 71, 3.

68 Lit.: «El-que-es-por-sí-mismo».

${ }^{69}$ Strom., V, 82, 1. Diversos comentarios a estas palabras del Alejandrino pueden verse en W. Völker, Der wahre Gnostiker nach Clemens Alexandrinus, (Texte und Untersuchungen zur Geschichte der altchristlichen Literatur 57; Berlin 1952) 94; A. ORBE, Hacia la primera teología de la procesión del Verbo. Estudios Valentinianos, vol. I/1-2 (Analecta Gregoriana 99-100; Romae 1958) 101-110; J. FERGuSON, «The achivement of

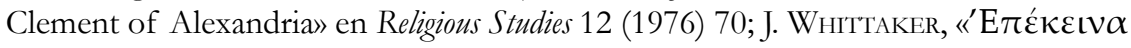

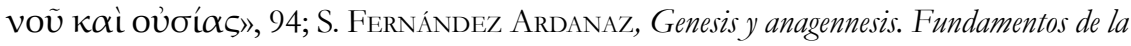
antropología cristiana según Clemente de Alejandría (Vitoria 1990) 218-219. Para los «nombres», cf. R. Mortley, Connaissance religieuse et herméneutique chez. Clément d'Alexandrie (Leiden 1973) 189-190. 
que acompañará la historia del pensamiento humano a lo largo de los siglos: si Dios es uno y trino, como nos dice la revelación, cla idea que tenemos de Dios por la filosofía puede llamarse verdadero conocimiento sobre Dios? ¿Se puede decir que Anaxágoras no conoció a Dios, únicamente porque no conoció a Dios como creador? ¿Se puede decir que Platón no conoció a Dios, solo porque no tiene el concepto de creación que manifiesta la revelación cristiana?

Clemente lucha por defender sus ideas. No tiene miedo en afirmar su plena convicción sobre la posibilidad de que la razón pueda acceder a determinadas verdades, parciales, sin duda, pero siempre verdades: «Por consiguiente, bien se diga que los griegos profesaron accidentalmente algo de la verdadera filosofía, ese accidentalmente es economía divina (puesto que no se querrá divinizar lo que acontece espontáneamente a nuestro gusto); o bien [se diga que] por coincidencia, esa coincidencia no es impremeditada ${ }^{70}$. Por otra parte, si se dijera que los griegos tuvieron alguna razón natural, sabemos que uno es el creador de la naturaleza» ${ }^{71}$. En definitiva, la razón, argumentando conforme a su naturaleza, no puede contradecir la fe, pues el mismo Dios es el autor de ambas. Creador de todos los bienes, lo es también de la inteligencia humana, cuya naturaleza consiste precisamente en conocer la verdad, y no se la puede despreciar ni antes ni después de haber aceptado la revelación.

En este orden, Clemente distingue la doble función de la razón, antes y después de la revelación. Antes de la venida de Cristo la razón es indispensable a los griegos para alcanzar la salvación; después de la revelación la razón es útil para conducirlos a la justicia. Y en esta segunda etapa, Clemente distingue dos momentos: la utilidad de la razón antes de aceptar el cristianismo, y el interés o función de la razón después de haber aceptado el cristianismo. En el primer momento, la razón «constituye una propedéutica para quienes pretenden conseguir la fe mediante demostración racional $\rangle^{72}$. Es decir, prepara el camino a la doctrina por excelencia, hace sabio al hombre, preforma su carácter, lo prepara para dejarse penetrar de

70 En este parágrafo Clemente propone todas las soluciones al problema sobre el origen de la filosofía griega; E. MolLAND, The Origin, 123-128, estudia esas soluciones.

71 Strom., I, 94, 1.

72 Strom., I, 28, 1. Sobre el tema de la fe simple y la fe «demostrada» cf. G. Lazzati, Introduzione, 66s.; A. Brontesi, La soteria, 278, nota 16; S. R. C. Lilla, Clement, 57 y 138-140. Para la razón y la filosofía como propedéutica, cf. W. Bierbaum, Geschichte, 256-261. 
la verdad; sin duda la razón es para el hombre una señal de sabiduría, una incitación a ocuparse de Dios. La razón es una propedéutica para le fe, precisamente por su misma naturaleza, que no es otra que la de buscar el sentido de la propia vida y, como consecuencia, al Autor del universo en el que vivimos. Así pues, la razón, en el pensamiento de Clemente, está abierta a la fe por su misma naturaleza; no se pone al lado de la fe, en paralelo, concordando con ella por una fortuita coincidencia o armonía preestablecida, sino sobre todo porque la fe comienza donde termina la razón, en perfecta continuidad, en perfecta coherencia, creando una simbiosis que en vez de ser una pérdida de la naturaleza o de la sobrenaturaleza, de la razón o de la fe, es un provecho para ambas, es una potencialidad entre ambas, porque cada una cumple con su misión propia, querida por Dios mismo, autor de una y otra.

Nos falta por analizar el segundo momento. ¿Cuál es el papel que desempeña la razón en el ya creyente? El Alejandrino resuelve el problema, como es obvio, afirmando que la razón -ya lo hemos insinuado anteriormente- es la defensa de la fe contra los ataques del error ${ }^{73}$, aunque no sea este el fin principal ni el más directo de la razón respecto a la fe ya aceptada. Respondiendo a los que le objetaban que se puede ser fiel cristiano incluso sin saber leer, Clemente cuida de establecer positivamente la finalidad principal de la razón frente a la fe. Después de afirmar que es imposible sin estudio comprender la doctrina de la fe, prosigue: «Aceptar lo que se dice con verdad, y rechazar lo ajeno [a la verdad] no lo infunde la fe sencilla, sino la fe relacionada con el aprendizaje $^{74}$. Mas si la ignorancia es falta de educación, al mismo tiempo es también falta de conocimientos. La enseñanza inspira la ciencia de las cosas divinas y humanas» ${ }^{75}$. No se puede ser más claro y a la vez más equilibrado. Al Alejandrino no le importa que pueda haber personas que

73 Cf. Strom., I, 100, 1.

74 Para la distinción de estas dos clases de fe, cf. Strom., I, 99, 1. A Clemente no le importa aceptar la terminología de sus adversarios herejes, pero difiere de ellos en su razonamiento: la salvación depende ciertamente de la fe, pero no existen dos clases de fe diversas que den origen a dos clases de salvación. El Alejandrino habla de dos clases de fe porque existen diversas clases de respuesta a la única salvación. El punto de partida es el mismo para todos los hombres: la fe sencilla o común; la meta se diversifica según los méritos de cada uno: la fe relacionada con el aprendizaje.

75 Strom., I, 35, 2-3. No se trata de cualquier enseñanza, sino de la divina. En este sentido, la enseñanza es sinónimo del término sabiduría, con la peculiaridad de que la primera se refiere al método y la segunda a los contenidos del aprendizaje. 
se salven «sin saber leer», sin hambre de una gran cultura. Él defiende la necesidad, como principio general, de profundizar en la fe, de poseer una inteligencia mejor iluminada y más segura. Dios no quiere que quien ha creído permanezca inerte respecto a la verdad. La incitación evangélica: «Buscad y encontraréis» ${ }^{76}$, se convertirá en nuestro Autor, al igual que en otros contemporáneos suyos, ortodoxos y herejes, en el aguijón constante que le estimula por el camino hacia la Verdad.

\section{Los caminos de la razón}

Son muchos y variados los senderos que utiliza la razón humana para acceder al conocimiento de la verdad. La razón comparte desde su misma existencia la información y el derecho a expresarse. En esta perspectiva tendríamos que hablar de aquellas fuentes y caminos que son meramente instrumentos materiales, como pueden ser las distintas formas del lenguaje, escrito o hablado, y los diversos géneros literarios que dicho lenguaje adopta en sus distintas formulaciones. Los escritores cristianos de los primeros siglos son judíos y también fundamentalmente paganos cultos. Ellos son los herederos de tradiciones en las que existen múltiples formas y modelos literarios de manifestar los hallazgos de la razón humana. Para transmitir el mensaje original cristiano, ¿cómo ha utilizado Clemente de Alejandría las formas y modelos literarios que tenía a su disposición? ¿De qué manera ha innovado y cómo se pueden comprender estas innovaciones? También en este sentido más inanimado, Clemente de Alejandría sabe recuperar el uso de la razón, proporcionado a la verdadera condición del hombre, para asegurar la comprensión de la Verdad (con mayúscula), así como la transmisión de la misma a sus contemporáneos.

Una mirada, aunque sea superficial, a sus obras principales, Protréptico, Pedagogo y Stromata, recuerdan a otros autores paganos que tenían los mismos objetivos que nuestro maestro cristiano, aunque con otras perspectivas, y que emplearon los mismos procedimientos literarios ${ }^{77}$. Nos estamos refiriendo a la influencia del género apologético, en sus vertientes de anuncio y de solicitud concreta. Pero no quisiéramos detenernos en esta fuente de inspiración del Alejandrino, sin duda interesante para comprender mejor la homonimia del maestro cristiano con sus antecesores paganos: nos lle-

\footnotetext{
Mt 7, 7; Lc 11, 9.

77 Es este punto es clásico el trabajo de W. JAEGER, Cristianismo primitivo y paideia griega (México-Buenos Aires 1965).
} 
varía un tiempo del que no disponemos en este momento y en el que ya se han detenido otros investigadores ${ }^{78}$. Permítasenos decir tan solo que las tres obras más señeras del Alejandrino pueden ser clasificadas dentro del género de la apologética, aunque no revelen perfectamente la forma clásica de la apología, sino más bien la del discurso protréptico, y distinguiendo también si los destinatarios son paganos, simples cristianos o ya con alguna formación de la doctrina revelada por Dios.

También merecería un detenimiento pormenorizado de las otras obras menores de Clemente como son sus Extractos de Teódoto, las Éclogas proféticas e incluso su discurso homilético titulado ¿Qué rico se salva? Estos tres escritos son reflejo de otras tantas formas literarias ya utilizadas por los autores que precedieron a nuestro maestro alejandrino, pero también su estudio pormenorizado nos llevaría lejos de los objetivos que ahora nos hemos planteado.

La misma obligación temporal nos incita a prescindir de otras ayudas literarias de las que se sirvió nuestro maestro cristiano, como, por ejemplo, la crítica, la exhortación y otros géneros que esclarecen de forma peculiar la epistemología de Clemente, y que también fueron empleados por sus predecesores paganos. El complejo puzzle de citas de autores paganos que nos presenta el Alejandrino en sus obras constituye otro entretenimiento científico que le relaciona directamente, en sentido positivo o negativo, con las argumentaciones y métodos de otros tantos escritores que le precedieron en el uso de las diversas formas de presentar los razonamientos humanos ${ }^{79}$, pero el tratamiento de su solución también sobrepasaría los límites que se nos han concedido para esta ocasión.

Más bien quisiera fijar la atención en uno de los métodos o procedimientos que adopta nuestro Autor en su acceso a esa Verdad con la que él desea identificarse. También desde esta perspectiva serían varios los aspectos a contemplar, pero pensamos exponer brevemente uno que nos parece paradigmático y nuclear en el pensamiento de Clemente. Nos estamos refiriendo al uso que hace del alegorismo en sus obras.

78 Cf. J. Bernard, Die apologetische Methode bei Klemens von Alexandrien. Apologetik als Entfaltung der Theologie (Leipzig 1968).

$79 \mathrm{Al}$ respecto, cf. L. E. Rossi, «I generi litterari nella patristica» en AugR 14 (1974) 381-699. 
Es conocido cómo nuestro Autor aplica con amplitud la interpretación alegórica a la Sagrada Escritura ${ }^{80}$. Esta interpretación, en efecto, se impondrá cada vez que el sentido literal de la Escritura comporta una contradicción interna, o una declaración indigna de Dios. Ciertamente Clemente, en su lectura de la Biblia, se abre tan ampliamente a esta figura retórica que podría decirse que constituye una de las fuentes inspiradoras de su pensamiento. Sin duda, el Alejandrino también cuenta con el incentivo de que san Pablo mismo utiliza también este método exegético e incluso otros autores cristianos que le precedieron en el uso del mismo, como pueden ser el Pseudo-Bernabé o Hipólito de Roma, por ejemplo. Pero él conocía también que este método se aplicaba en la civilización de los autores paganos. Sin duda, esta dualidad de inspiración, pagana y cristiana, se transparenta en la dualidad de su vocabulario técnico, donde junto a términos característicos del Nuevo Testamento aparecen palabras propias

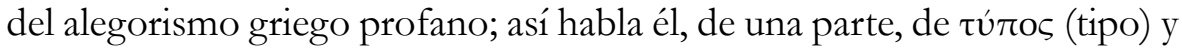

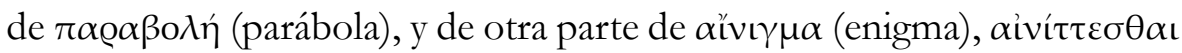

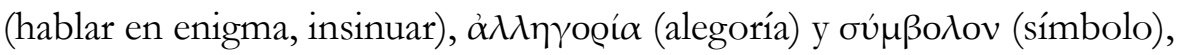
sin que, además, introduzca prácticamente diferencia alguna entre los comportamientos de cada uno de estos términos. Ciertamente nuestro Autor no es el único, entre los escritores cristianos, que se deja influenciar por el alegorismo profano, pero lo que asombra y extraña es que poco antes que él no era visto con buenos ojos esta manera de proceder.

La dialéctica dulce y suave del Alejandrino, más que señalar un abismo entre la alegoría pagana y la cristiana, insiste en su continuidad, y presenta a una como la prolongación y perfeccionamiento de la otra, y por ello señala en toda forma religiosa la presencia de una enseñanza secreta y la necesidad de un progreso alegórico, tanto para ocultar enigmáticamente dicha enseñanza como para expresarla con claridad, aunque parezca paradójico. En Clemente la alegoría se manifiesta como la ley misma de toda religión. Esta actitud simpática (en sentido etimológico) del Alejandrino

80 Cf. Este aspecto ha sido estudiado con profundidad por J. LeBreTon, «La théorie de la connaissance réligieuse chez Clément d'Alexandrie» en RechSR 18 (1928) 457-488; J. Munck, Untersuchungen über Klemens von Alexandria, (Forschungen zur Kirchen und Geistesgeschichte, 2; Stuttgart 1933) 212-223; Cl. MondéSERT, «Le symbolisme chez Clément d'Alexandrie» en RechSR 26 (1936) 158-180; ID., Clément d'Alexandrie. Introduction à l'étude de sa pensée religieuse à partir de l'Écriture, Théologie, 4, (Paris 1944) 47-62; 88-91; 131-152; W. DEN WoER, De allegorese in het Werk van Clemens Alexandrinus (Leiden 1940); etc. 
es bastante rara en el ambiente cristiano de la época, y justifica nuestra atención.

En el libro quinto de sus Stromata encontramos un verdadero tratado de la alegoría, considerada como fenómeno de la razón humana y también de toda religión, hasta el punto que se puede presentar a su autor como el primer historiador de las religiones en el sentido moderno de la expresión. El Alejandrino observa que, desde siempre, la actividad religiosa ha ido acompañada de un cierto esoterismo, que él representa por la noción de adyton, santuario o recinto reservado aun pequeño número de personas, $\mathrm{y}$ por la utilización cultual del velo. Esta disimulación de la enseñanza sagrada bajo el resguardo del enigma, característico de la interpretación alegórica, no es exclusiva de los egipcios, dirá Clemente, sino que también es familiar a los griegos, cuyos más célebres oráculos no hablan abiertamente. Estas son sus palabras directas: «Podría decirse que todos los que han tratado acerca de Dios, bárbaros y griegos, han ocultado los comienzos de las $\operatorname{cosas}^{81}$, pero han transmitido la verdad mediante enigmas y símbolos, con alegorías, metáforas y otras figuras parecidas; así eran los oráculos entre los griegos, y por eso Apolo de Delfos es denominado el Loxias» ${ }^{82}$.

La disimulación de la verdad desborda el campo propiamente religioso, pues la han usado los filósofos de todos los tiempos y lugares y abarca en realidad toda forma de expresión. El panorama que presenta el Alejandrino tiene sus inicios en los Siete Sabios de Grecia, continúa con los poetas más famosos -como Orfeo, Homero, Hesíodo, y otros-, transcurre por la escritura epistolográfica, jeroglifica y pictográfica de los egipcios -bien conocida por él mismo y sus lectores alejandrinos-, y con ejemplos bíblicos, tanto del Antiguo Testamento como del Nuevo; finalmente serán los filósofos

81 El vocablo $\pi \varrho \alpha ́ \gamma \mu \alpha \tau \alpha$ (realidades, seres, cosas) es un término filosófico que designaba las ideas platónicas, y entre los cristianos indica los misterios de la fe: C. NARDI, Clemente Alessandrino. Estratti profetici (Biblioteca Patristica 4; Firenze 1985) 121-122. E. F. Osborn, The Philosophy, 169-170, indica las razones por las que Clemente se sirve del simbolismo.

82 Strom., V, 21, 4. El sobrenombre de Apolo (el oblicuo) se debe a la ambigüedad de sus oráculos y símbolos. Sobre el esoterismo en el Alejandrino, cf. E. L. ForTin, «Clement of Alexandria and the esoteric tradition» en Studia Patristica IX/3 (1966) 45-46; J. PÉPIN, Mythe et Allégorie. Les origines grecques et les contestations judéo-chrétiennes (Paris 1976) 267; R. MorTlEy, Connaissance religieuse, 181-187. Sobre la interpretación de A. Deiber, «Clément d'Alexandrie et l'Égypte» en MLArchC 10 (1904) 22-32, a este pasaje, cf. C. MONDÉSERT, Le symbolisme, 163, nota 12. 
más preclaros en los que se fija nuestro Autor para cerrar esta visión panorámica que ofrece sobre la importancia del método alegórico.

¿Pero cuál es la razón que ha podido suscitar esta extensión universal de la disimulación por medio de la alegoría? Clemente expone los diversos beneficios que puede reportar esta forma de expresión. Así, en primer lugar, el método alegórico permite al escritor concentrar su mensaje en pocas palabras, y al exégeta probar su perspicacia y su laboriosidad: «La práctica de la interpretación simbólica -escribe- es muy útil para muchas cosas: para colaborar a la verdadera teología, para la piedad, para demostrar la inteligencia, para ejercitarse en la concisión y como prueba de sabiduría» ${ }^{83}$. Al permitir la brevedad, facilita la memoria, y al rodearse de oscuridad, estimula la investigación; estos son otros tantos frutos benéficos del alegorismo.

Pero sobre todo, una cierta disimulación da un mayor valor a lo que, expuesto de forma escueta, perdería su encanto. En verdad, una declaración obvia no autoriza más que una sola interpretación, mientras que la alegoría se deja explicar de varias maneras; ésta es su riqueza. Así lo expresa nuestro Autor, después de exponer una somera lista de autores que han utilizado la alegoría: «La vida será insuficiente para enumerar la multitud de los que filosofan mediante símbolos. Los escritos de la filosofía bárbara han empleado esos mismos [símbolos] por razón de la memoria, la concisión y el interés por la verdad. Así, quieren en realidad que la auténtica filosofía y la verdadera teología ${ }^{84}$ estén al alcance solamente de quienes las practican asiduamente, y de los que dan prueba conforme a la fe y a la vida. Ahora bien, anhelan que tengamos necesidad de un intérprete y de un guía; así también se apreciarían más y servirían a los dignos de ellas, y estarían menos expuestos al error, al recibirlas de los competentes como es debido. Por otra parte, todo lo que se transparenta a través de un velo muestra la verdad de un modo más grande y augusto ${ }^{85}$. $\mathrm{Al}$ igual que los frutos vistos debajo del agua, y las formas que mediante velos transparentes permiten adivinar algunas alusiones en ellas. Así, las formas inundadas de luz se hacen por eso mismo convincentes, y las

83 Strom., V, 46, 1.

84 En la época en que escribe el Alejandrino, la «teología» era una parte de la filosofía, especialmente entre los etoicos: B. D. Dupuy, En los orígenes de la noción de teología: profecía y teología en Clemente de Alejandría (Santander 1975) 140.

85 Para la importancia metodológica del velo en nuestro autor, cf. R. MORTLEY, Connaissance religieuse, 181-187. 
manifiestas son percibidas de manera uniforme. Ahora bien, se puede hacer uso de varias interpretaciones, como nosotros lo hacemos, de lo que se dice veladamente. De esta manera, el inexperto e ignorante vacila, mientras que el gnóstico comprende» ${ }^{86}$. El texto clementino es amplio, pero a la vez condensa su pensamiento en el punto que nos ocupa.

La última ventaja, que entraña la disimulación alegórica señalada en esas palabras resulta en definitiva ser la principal: no imputar a un Dios celoso el ocultar su misterio, sino más bien el no permitir que la revelación religiosa se encuentre al alcance de una multitud indigna, puesto que la expresión metafórica excita en los espíritus perezosos el gusto por la investigación. La simpatía por la alegoría pagana nos la manifiesta Clemente con unas palabras de Sófocles, a la vez que ilustra esa idea sobre que la oscuridad de las revelaciones divinas no repugna al sabio, mientras que los mensajes más claros se le escapan al necio. Los versos del poeta trágico dicen: «También yo conozco perfectamente que Dios es así; / que siempre predice lo enigmático a los sabios, / pero es maestro mediocre e insignificante para los torpes» ${ }^{87}$.

El mérito de nuestro Autor no reside en la originalidad de las ventajas del método alegórico que hemos expuesto; en verdad, la mayoría de ellas se pueden encontrar bajo la pluma de otros escritores, tanto paganos como cristianos. La originalidad de Clemente consiste en haberlas puesto en práctica: las ventajas de la alegoría en general, no solo la alegoría bíblica. Su utilización se podría sistematizar de la siguiente manera: la expresión alegórica permite al escritor ser sobrio y le impide extenderse en discursos inútiles y, por ello, poco fieles; por la brevedad misma, la alegoría alivia la memoria del lector; por su dificultad de inteligencia, facilita la ocasión de mostrar su talento y su piedad; como oscura que es, incita la curiosidad, aguijonea la pereza natural, estimula la investigación; como imprecisa, autoriza una benéfica pluralidad de interpretación; en cuanto a la revelación misma, la alegoría custodia su nobleza, que una tradición excesivamente explícita podría desprestigiar, y la mantiene lejos de la atención de los indignos.

Estas eran las ventajas de la disimulación de las más altas verdades que alcanza la razón humana por medio de la alegoría; ¿cómo iba a privarse de ellas el cristianismo? Por ello nuestro Alejandrino asume y recapitula todo

\footnotetext{
86 Strom., V, 56, 1-57, 1.

87 Sófocles, Fragm. inc., 704.
} 
lo que los intentos insuficientes y torpes, pero también providenciales, de la antigüedad pagana habían conseguido por este camino. Parece más que razonable la pregunta de Clemente: «Si quienes ocultaban las opiniones humanas impidieron que los ignorantes tuvieran acceso a ellas, ¿no convenía que la contemplación santa y bienaventurada de la auténtica realidad esté disimulada más que cualquier otra cosa? $\rangle^{88}$. Nada tiene de extraño, pues, que los autores del Antiguo y del Nuevo Testamento hayan respondido a estas exigencias, poniéndolas en práctica, o al menos han recomendado la alegoría como procedimiento de expresión de la razón humana. Clemente cita o evoca distintos pasajes de la Sagrada Escritura, por los que pretende probar cómo los escritores sagrados de las páginas inspiradas por Dios no han dejado de usar esta ley de toda revelación religiosa.

Finalmente, en materia de disimulación alegórica de la verdad religiosa, el cristianismo no tiene nada que envidiar a la antigüedad pagana. Por ello Clemente termina su estudio sobre la alegoría, antes de pasar a otro tema, con estas palabras: «Demostrada la antigüedad del simbolismo y su uso no solo por parte de nuestros profetas, sino también por la mayoría de los griegos antiguos y por no pocos de entre los pueblos bárbaros, es necesario tratar igualmente de los misterios de los iniciados» ${ }^{89}$. De esta manera también nosotros pasamos al análisis de la otra expresión que requiere nuestra atención: la fe.

\section{La fe como facultad humana}

La noción que nuestro Autor presenta de la fe es de una gran origina-

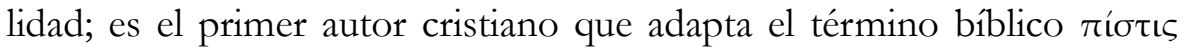
a la lógica aristotélica y estoica. Por esa actitud concordista, Clemente tiene sus recelos en explicar la fe cristiana con unas categorías que la eleven por encima de la razón. Esta postura del Alejandrino frente a la fe, tiene sus riesgos ciertamente, pero era necesaria y obligatoria, pues la pistis cristiana era tenida como sinónimo, al menos para los grandes adversarios del cristianismo, de ingenuidad o simpleza. Se localizaba muy alejada de la phronesis y del logismos, que se encontraban en la base del concepto griego de conocimiento. De una parte se acusaba a la pistis cristiana de una falta de base científica, y de otra, algunos pensadores, como Celso ${ }^{90}$,

\footnotetext{
88 Strom., V, 58, 5.

89 Strom., VI, 4, 2.

90 Cf. Orígenes, Contra Celsum, $1,9$.
} 
por ejemplo, comparaban la pistis a una ciega suposición o incluso a un prejuicio arbitrario.

Desde el punto de vista de la razón, es verdad que en Platón la fe, al

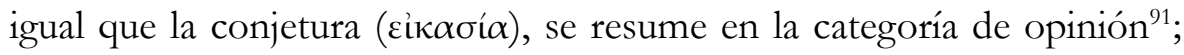
la pistis formaba parte de una comprensión inferior, que tenía por objeto la realidad etérea del devenir. En Aristóteles se asigna a la pistis un papel más importante: la facultad que juzga y conoce los primeros principios

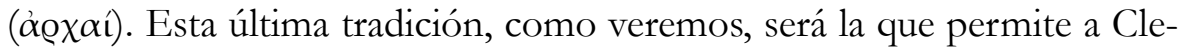
mente demostrar el respeto racional del concepto bíblico de la tíotıs. En efecto, el maestro Alejandrino consigue transmitir una exposición de la fe que es válida filosóficamente y que no deforma el sentido religioso del término tal como es conocido en la Biblia. De esta manera convertirá la pistis en genuino fundamento de conocimiento para el hombre ${ }^{92}$, y la convertirá en el eslabón continuador de la razón en el hallazgo humano de la verdad.

Así pues, la tarea primordial de nuestro Autor no será otra que demostrar la coherencia de la razón humana con la fe cristiana. Además, como hombre apostólico que es, Clemente presentará su proposición con las siguientes palabras: También a quienes solicitan la sabiduría que ya tienen hay que presentarles lo que les es familiar, para que lleguen por lo que les es propio y con facilidad a la fe de la verdad ${ }^{93}$. Este es también nuestro objetivo presente: demostrar cómo la naturaleza de la fe cristiana no contradice a la razón humana, sino que es una prolongación de la misma. Dejamos de lado otras consideraciones importantes de la noción de fe que posee el Alejandrino, pero que también nos apartarían de la meta propuesta. Así pues, baste recordar que, para nuestro Maestro: «la fe es un bien interior que confiesa la existencia de Dios, aunque sin abarcarlo, pero lo glorifica

91 Cf. Platón, Teeteto, 200 D.

92 En este punto nos distanciamos de H. A. Wolfson, La filosofia dei Padri della Chiesa, 112s., quien afirma que la fe es una «suposición pasional», una forma segurísima de conocer una idea; es decir, no sería fundamento del conocimiento, sino una facultad para dicho conocimiento.

93 Strom., V, 18, 6. Con estas palabras Clemente no pretende afirmar que el libre arbitrio del hombre pueda fecundar, sin el concurso divino, la cualidad del alma y conducirla al conocimiento de la salvación; dice solo que eso es necesario, aunque insuficiente. Solo por gracia seremos salvados, lo mismo que no seremos salvados sin obras buenas: L. Gallinari, La problemática, 85. 
como existente» ${ }^{94}$. Se trata de un germen depositado en el alma, cuyo objetivo no es tanto conocer a Dios cuanto comprender la enseñanza que Cristo transmite, y recibir la ciencia que Dios comunica a los que le buscan a través de su Hijo ${ }^{95}$.

El pensamiento de Clemente sobre la fe se puede resumir de la siguiente manera: La inteligencia de la palabra de Cristo es un don concedido por Dios a los que han guardado con fidelidad y han hecho fructificar con atención el depósito doctrinal que se les ha transmitido con ese doble objetivo. Al igual que la razón, la fe es un don divino que tiene por meta, lo mismo que la razón, el conocimiento de la verdad; aunque en el caso de la fe ese nombre, el de la verdad, haya que escribirlo con letras mayúsculas.

Desde este particular punto de vista, la fe consiste en una toma de posición de cara a Dios que manifiesta, una adhesión individual a la persona de Cristo. Al reconocerle como su Dios y Salvador, el hombre decide libremente, con pleno conocimiento de causa, confiar en su palabra y obedecer a sus mandatos; se cuelga de Cristo para edificar su propia salvación juntamente con Él. Esta es la actitud del hombre creyente, que presta su fe a su Maestro y le entrega la formación de su espíritu y la conducta de su vida. Mientras que la razón humana está siempre sometida a la garantía del maestro, al que puede criticar ulteriormente, la palabra de Dios admitida por la fe se impone por su misma autoridad y el creyente la recibe «sin investigar», «sin discutir ni dudan». El argumento pitagórico de «el maestro lo ha dicho» es la razón más fuerte y profunda que el hombre posee para dar su confianza a la palabra de Dios.

Ciertamente, en Clemente la razón y la fe se necesitan entre sí; la fe tiene sus propias razones y constituye un verdadero argumento. Razón y fe se complementan y el principio que las relaciona es muy claro y preciso en la mente del Alejandrino: ambas son concedidas por el mismo Creador, y las dos constituyen, en idéntico servicio, el fundamento y andadura para alcanzar la gnosis, que es la perfecta simbiosis entre razón y fe. Este término, gnosis, constituirá la meta de ambas ${ }^{96}$. En efecto, nada hay anterior a la razón humana, pero el coronamiento del conocer humano

\footnotetext{
94 Strom., VII, 55, 2.

95 Cf. Strom., VII, 55, 1-58, 6.

96 Cf. J. Moingt, «La gnose de Clément d'Alexandrie dans ses rapports avec la foi et la philosophie» en RSR 37 (1950) 195-251.
} 
lo representa la fe, que es la prolongación de aquella y que se basa en sus mismos estatutos.

Al igual que la razón humana, también la fe tiene la posibilidad y la necesidad de un progreso. Este problema planteado por Clemente lo resuelve en el primer libro del Pedagogo, mediante la exégesis de los términos niño y leche, que es el alimento de la palabra de Dios, dado en la predicación. La manera en que el maestro de Alejandría resuelve el problema en su Pedagogo contiene en germen todos los desarrollos que los Stromata aportarán. La fe es para él la perfección de la ciencia y no le falta nada porque es perfecta y acabada en sí misma. Pero veamos algunos de los desarrollos de la fe en el pensamiento del Alejandrino.

\section{Las «razones» de la fe}

En primer lugar, dice Clemente que «la fe que algunos griegos calum-

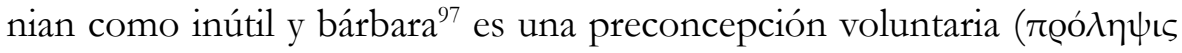

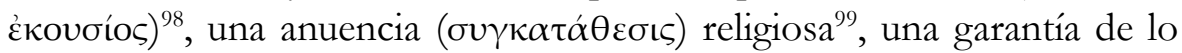
que se espera, una prueba de las cosas que no se ven ${ }^{100}$, según el divino

${ }_{97}$ El término «bárbara» tiene aquí un matiz despectivo. La actitud que refleja este texto no se entiende muy bien con la manifestada en Strom., II, 1, 1. Para la valoración de la fe en los filósofos griegos, cf. J. PÉPIN, «De la philosophie ancienne à la théologie patristique» en Collected Studies Series vol. II (London 1986) 139-144.

98 Es decir, una especie de intuición libre que precede a cualquier operación del espíritu humano. Para la definición epicúrea de $\pi \varrho o ́ \lambda \eta \psi \iota \varsigma$ (anticipación, pre-concepción) y sus relaciones con Clemente, cf. S. LiLla, Clement of Alexandria, 129-130; A. Dessi, Elementi Epicurei, 417; L. RIZZERIO, «The notion of akolouthia as logic of truth in Clement of Alexandria» en Rivista Di Filosofia Neo Scolastica 79/2 (1987) 175-195; E. F. Osborn, «Arguments for Faith in Clement of Alexandria» en VigChr 48 (1994) 4; ID., «La Bible inspiratrice d'une morale chrétienne d'après Clément d'Alexandrie» en C. Mondésert, Le monde grec ancien et la Bible (Paris 1984) 136-137. La fe consiste, por parte humana, en un acto libre: R. MORTLEY, Connaissance religieuse, 110; y la «preconcepción» es la base en la que se apoya cualquier búsqueda (114).

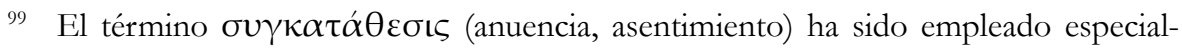
mente por los estoicos; significa la positiva reacción para cuidar de la sensaciónpercepción, el acuerdo del espíritu con las percepciones; es el asentimiento interior que nosotros damos a lo que parece evidente. Clemente ha recibido la identificación «anuencia»-«fe» de dichos filósofos a través de Antíoco y sus discípulos: S. LiLla, Clement of Alexandria, 128-129. También, cf. H. A. BLAIR, «Allegory, Typologie and Archetype» en E. A. Livingstone (ed.), en Studia Patristica vol XVII/1 (1982) 266.

$100 \mathrm{Hb}$ 11,1-2. Para la relación fe-esperanza, cf. V. Messana, «Teologia della speranza nella paideia de Clemente Alessandrino» en Salesianum 40 (1978) 493-494; L. PAdovese, 
Apóstol» ${ }^{101}$. Esa preconcepción voluntaria es como un fijar la atención en una cosa evidente y en la clara inteligencia de un objeto; así, no se puede indagar, ni dudar, ni mucho menos concebir una opinión, ni refutar nada sin la preconcepción ${ }^{102}$. Ya Heráclito había dicho que si uno no espera lo que está más allá de la esperanza, no lo encontrará, porque le será imposible examinarlo y entenderlo ${ }^{103}$. Incluso el gnóstico Basílides, aunque negara la libertad de la fe, se dio cuenta de que la fe es el asentimiento del alma a las cosas que no están presentes a los sentidos, por ello la fe constituye una preconcepción razonable anterior a la misma comprensión. Se trata de una expectación, de una confianza. Por eso-concluirá Clemente- «nosotros creemos en aquel en quien hemos confiado, para gloria de Dios y salvación nuestra. Y hemos puesto nuestra confianza en el único Dios, porque sabemos que Él no quebrantará las buenas promesas que nos ha hecho, ya que por eso han sido realizadas y por Él nos las ha concedido con benevolencia» ${ }^{104}$.

La función de la prólesis es hacer posible la práctica de la razón, cuando la percepción tiene que enfrentarse a un complejo de sensaciones. Por medio de la preconcepción reconocemos diversas clases de cosas y la razón puede seleccionar aquella que pone en marcha el acto de percepción. Es decir, la fe, como pre-conocimiento se presenta como el punto de partida indispensable para alcanzar la meta cognoscible a la razón. Con otras palabras, no razonamos sobre cualquier cosa de la que no hayamos tenido un conocimiento previo, que es el que facilita la fe. De alguna manera, la preconcepción constituye la condición previa de toda argumentación, opinión o actividad lógica.

Pero la fe, además de preparación es también asentimiento; no se queda en el aire como suspendida. «Otros han definido la fe como un

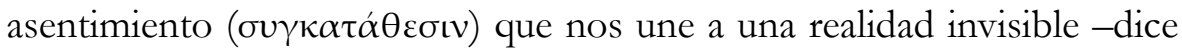

«La speranza “del vero gnostico" secondo Clemente d'Alessandria» en Lau 25 (1984) 146.

101 Strom., II, 8, 4. Para Clemente, como para otros escritores cristianos de la época, el autor de la Carta a los Hebreos es san Pablo, aunque también Orígenes, por ejemplo, lo pone en duda, como nos recuerda Eusebio de Cesarea, Hist. ecl., VI, 25, 11-13 (BAC 350, 396).

102 Cf. Strom., II, 16, 3.

103 Cf. Heráclito, Fragm., 22 B 18; P. Valentín, «Héraclite et Clément d'Alexandrie» en RSR 46 (1958) 33-34.

104 Strom., II, 28, 2. 
el Alejandrino-, lo mismo que la demostración es un asentimiento con evidencia racional dado a una realidad que se ignoraba. Ahora bien, si la fe es una elección deliberada, puesto que tiende hacia un objeto, tal deseo es reflexivo, y si por otra parte la elección deliberada es un principio de acción, también la fe es principio de una búsqueda consciente, como si uno procurase anticipadamente la demostración mediante la fe» ${ }^{105}$. Tenemos aquí los dos elementos que nos interesan: preconcepción y asentimiento; una es previa al razonamiento y el otro es posterior; pero ambos integran la definición de la fe clementina. La prólesis es voluntaria y libre, se trata de una verdadera elección, mientras que el asentimiento es una decisión, un decir sía lo elegido. Para Clemente, pues, la fe proporciona el fundamento de la opción anticipada de la razón y la decisión que supone el seguir la mejor posibilidad en el comienzo para razonar bien.

Además, con las palabras citadas, nuestro Autor trata de convencer a los filósofos y de contrarrestar el influjo nocivo de los gnósticos heterodoxos. Los primeros afirmaban que la fe era inferior al conocimiento, mientras que los segundos negaban que la fe fuera una cuestión de opción libre. A platónicos y estoicos les dirá: «Toda opinión, juicio, hipótesis y aprendizaje ${ }^{106}$, acciones de las que se compone siempre nuestra vida y nuestra convivencia con los hombres, constituyen un asentimiento. Y este no puede ser otro que la fe; incluso la incredulidad, en cuanto que es apostasía de la fe, demuestra la posibilidad del asentimiento y de la fe, pues no hay privación de lo que no existe» ${ }^{107}$. Los términos provienen del lenguaje estoico, pero la doctrina es distinta en Clemente. Lo que el autor cristiano desea reafirmar es la libertad. También es Aristóteles quien identifica el asentimiento con la $f e$, en cuanto que ambos actos son fruto de la elección libre del hombre ${ }^{108}$. La fe, como el asentimiento voluntario del alma, pro-

105 Strom., II, 9, 1.

106 Por parte de Dios, el aprendizaje humano supone una iluminación divina (cf. Strom., II, 48, 4), pero desde el lado humano implica un asentimiento, una obediencia libre o docilidad para escuchar a Dios mediante la fe.

107 Strom., II, 55, 1.

108 Cf. H. A. Wolfson, La filosofia dei Padri, 111-113; también es interesante este trabajo para la relación entre los términos estoicos y el aristotélico de la «fe», usados por Clemente (120). Para el asentimiento en perspectiva moral, cf. O. PRunET, La morale de Clément d'Alexandrie et le Nouveau Testament, (Études d'histoire et de philosophie religieuses 61 ; Paris 1966) 58-60. 
duce las buenas obras y la conducta recta, dirá Clemente ${ }^{109}$; fe y obras son los que, por parte del hombre, facilitan la auténtica salvación.

Incluso, faltando el asentimiento -concluye el Alejandrino- al ser humano le queda la fe. En efecto, dirá él, no preguntamos por las cosas que son evidentes (si es de día cuando es de día), ni sobre lo que jamás quedará claro (si el número de las estrellas es par o impar), ni tampoco proponemos cosas insolubles o irrefutables; sin embargo, a pesar de ello, la fe se mantiene íntegra porque su propuesta es algo infalible, Dios mismo, que es quien habla y apuntala lo que el hombre busca ${ }^{110}$.

Hasta aquí hemos hablado de dos elementos razonados de Clemente sobre la fe: la preconcepción y el asentimiento. Dando un paso más, el maestro Alejandrino afirmará que la fe necesita también de la percepción, para que tenga lugar el asentimiento. La fe es el escrutinio de las cosas que no se ven, como afirma la Carta a los Hebreos: «La fe es fundamento de las cosas que se esperan, prueba de las que no se ven» ${ }^{111}$. Moisés espera ver lo que es invisible ${ }^{112}$; espera porque cree, afirma Clemente, y ve con su mente los objetos y cosas del futuro. Así lo dice: «Porque también el que espera, como el que cree, ve con la inteligencia lo comprensible y lo futuro. Ahora bien, aunque afirmemos que algo es justo y digamos que también es bello, e incluso digamos que algo es verdad, no obstante, ninguna de esas realidades las hemos visto con los ojos, sino solo con la inteligencia» ${ }^{113}$. Se trata, pues, de una percepción inteligible. También la percepción y la sensación son escalones para la razón, pero no es menos auténtico que la fe avanza por las cosas que se perciben: «Aunque la sensación sea el peldaño de la ciencia, sin embargo la fe se hace primero camino mediante las cosas sensibles, luego abandona la opinión, aspira hacia lo que no es engañoso y descansa en la verdad $\rangle^{114}$. En este punto la razón y la fe hacen el mismo camino, aunque en planos diferentes.

\footnotetext{
109 Cf. Strom., V, 86, 1.

110 Cf. Strom., V, 5, 3-4.

$111 \mathrm{Hb} \mathrm{11,} 1$.

112 Cf $\mathrm{Hb} 11,27$.

113 Cf. Strom., V, 16,

114 Strom., II, 13, 3. Sobre el progreso de la fe hacia la verdad, cf. L. Rizzerio, «La nozio-

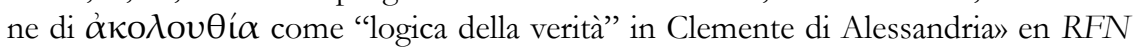
79/2 (1987) 188.
} 
Desde esta perspectiva, el Alejandrino afirmará que la fe es el oído del alma, por el que el hombre puede escuchar y comprender lo que el Señor dice. La fe del Maestro y del discípulo trabajan juntas hacia el único fin salvífico. También la fe es el ojo del alma que mira hacia el descubrimiento. El Alejandrino, como antes san Pablo, afirma que hay que tener unos ojos y oídos nuevos para mirar las cosas invisibles y eternas que hay en el cielo. En sentido contrario, también los evangelios inspirados afirman que la ceguera y la sordera son las enfermedades epistemológicas por excelencia. En definitiva, la salvación, o condenación, será pronunciada sobre aquellos que vieron, o no, en el hambriento, sediento, abandonado, desnudo, enfermo y preso, la presencia de su Señor ${ }^{115}$.

Así pues, la fe constituye una especie de sentido sobrenatural que predispone al alma a aferrarse a la verdad; pero así como la razón puede oír o ver entre celos o avaricias, pongamos como ejemplo, el creyente se encuentra firme, anclado seguro sobre la fe. El pensamiento de Clemente al respecto viene reflejado en las siguientes palabras: «Las voces hechizas de las sirenas manifiestan un poder sobrehumano e impresionan a quienes se encuentran en sus proximidades, disponiéndoles a escuchar sus cantos, aunque ellos mismos no quieran» ${ }^{116}$. En cambio la visión y audiencia de la fe no tienen esos obstáculos mediáticos, porque se fundamentan en el comportamiento del Hijo de Dios y en la escucha de la Palabra de Dios: «Hechos y dichos» del Señor constituyen los basamentos del edificio cognoscitivo de la fe, que da estabilidad y equilibrio a la razón.

Andando por el camino de la fe clementina y encontrándonos con la percepción, nuestro pedagogo alejandrino nos hace la siguiente pregunta; ¿dónde se puede ver y oír a Dios? Con la liberalidad y delicadeza que le caracteriza, Clemente responde: «Puede que nuestra demostración sea la única verdadera, en cuanto que emana de las divinas Escrituras, de los libros sagrados y de la sabiduría enseñada por Dios ${ }^{117}$, según el Apóstol.

115 Cf. Mt 25, 31-46.

116 Strom., II, 9, 7. Sobre la alegorización que Clemente hace del mito de Homero sobre Ulises y las sirenas, cf. J. DaniéLou, Histoire des doctrines chrétiennes avant Nicée: I. Théologie du Judéo-Christianisme, (Bibliotèque de Théologie; Tournai 1958) 91-92; trad. española, Cristiandad (Madrid 2004).

1171 Ts 4, 9. Sobre la autoridad de las Escrituras, cf. FR. BurI, Clemens Alexandrinus und der paulinische Freiheitsbegriff (Zürich und Leipzig 1939) 23-25; H. KARPP, «Die Bußlehre des Clemens von Alexandrien», en ZNW 43 (1951) 226; J. PALuCKI, «Principi fondamentali di una corretta esegesi nel pensiero di Clemente Alessandrino» en S. FELICI (ed.), 
También es un aprendizaje ${ }^{118}$ el obedecer los mandamientos, que significa tener fe en Dios. La fe es un poder de Dios, es la fuerza de la verdad» ${ }^{119}$. Ciertamente las Escrituras constituyen el mundo perceptible, donde recibimos la voz de Dios como prueba irrefutable; la fuerza de las Sagradas Escrituras es, como la atracción del imán, es la mayor seducción de la que dispone el hombre; sitúa a sus lectores, casi contra su voluntad, a recibir las palabras de Dios. «Por eso, quien cree en las divinas Escrituras hace sólido su criterio y de ahí que reciba como demostración irrefutable la voz de aquel que nos ha dado las Escrituras, de Dios ${ }^{120}$. Es decir, el hombre cristiano, el hombre de fe, tiene su prueba, basada sobre el conocimiento, en una obediencia que no es otra cosa que la fe en Dios. Incluso la fe más sencilla tiene ese conocimiento o racionalidad.

De esta manera el creyente se siente seguro, estable, mientras que el no creyente estará dominado por sus impulsos inestables y variables. La interpretación alegórica de Clemente viene una vez más en nuestra ayuda: Con razón está escrito: Caín, se alejó de la presencia de Dios, y habitó en el país de Nod, al oriente de Edén ${ }^{121}$. «Nod significa turbación, y Edén deli$\mathrm{cia}^{122}$. Las delicias son fe, gnosis, paz ${ }^{123}$; quien las desobedece es rechazado; y quien se cree sabio comienza por no desear ni siquiera prestar oídos a los divinos mandamientos, sino que se parece a quien todo lo importa de sí mismo, y se resiste, y se lanza por su espontánea voluntad en un mar

Esegesi e catechesi nei Pdri (sec. II-IV), (Bibl. di Scienze Religiose 106; Roma 1993) 118. Para la sabiduría enseñada por Dios, cf. J. WyTzes, «The Twofold Way I-II. Platonic Influences in the Work of Clement of Alexandria» en VigChr 14 (1960) 147.

$118 \mathrm{El}$ «aprendizaje» $(\mu \alpha \dot{\theta} \theta \eta \sigma \iota \varsigma)$ en el Alejandrino implica siempre la iniciativa del Maestro que imparte la instrucción; se trata, pues, de una iluminación conferida por el Maestro. Por el contrario, el aprendizaje griego consistía en la transmisión, de hombre a hombre, sobre conocimientos imperfectos y falibles como el hombre mismo.

119 Strom., II, 48, 3. Para la coherencia entre la fe y la verdad, cf. L. Rizzerio, La nozione

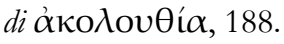

120 Strom., II, 9, 6.

121 Gn 4, 16.

122 Sobre la etimología de estos nombres, cf. U. Treu, «Etymologie und Allegorie bei Klemens von Alexandrien» en F. L. Cross (ed.) Studia Patristica, vol. IV (Oxford 1961) 197. Un breve comentario a este pasaje puede vese en R. MorTLEy, Connaissance religieuse, 116.

123 Cf. A. Kerrigan, «The Notion of "peace" in the Writings of Clement of Alexandria» en XXXV Congreso Eucarístico Internacional, Sesiones de Estudio, vol. II, (Barcelona 1954) 431. 
de olas agitadas; desciende desde el conocimiento del Inengendrado hacia los seres mortales y engendrados, pasando continuamente de una opinión a otra» ${ }^{124}$.

En esta misma línea encontramos en los Stromata que hasta la mis-

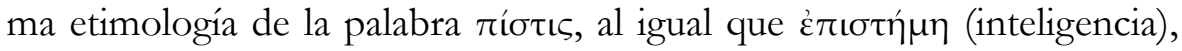

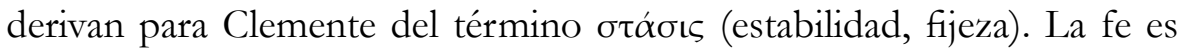
sinónimo de equilibrio y da al hombre esa estabilidad de la que carece la simple razón humana. Esta firmeza es la que ayuda al hombre a adherirse al objeto de su conocimiento, que no es otro que el manifestado en las Sagradas Escrituras. La conclusión del Alejandrino no se hace esperar: existe identificación de naturaleza entre el objeto conocido y la facultad que lo concibe; por eso, «la demostración que hemos denominado científica, genera la $\mathrm{fe}^{125}$ mediante la presentación y la explicación de las Escrituras ${ }^{126}$ a las almas deseosas de aprender; ésa sería la gnosis» ${ }^{127}$. Presentar la gnosis como el resultado conjunto de la razón y la fe nos llevaría excesivamente lejos en este momento. Quedémonos ahora con la idea de que la fe no puede ser vencida, según el Alejandrino, porque es Dios mismo quien viene en su ayuda mediante las Sagradas Escrituras ${ }^{128}$.

Ahora bien, el mayor castigo que merece un hombre no es por no creer en Dios, sino por pedir pruebas a la Providencia sobre su misma existencia, dirá el Alejandrino ${ }^{129}$. Con otras palabras, se nos recuerda que las Escrituras inspiradas por Dios constituyen también el criterio y primer principio del creyente, imposible de demostrar y recibir de él las demostraciones convincentes, como lo exige la naturaleza de todo primer principio. Clemente argumenta que los primeros principios no son demostrables, pues de lo contrario no serían primeros principios, sino

124 Strom., II, 51, 4-5. Clemente expone la naturaleza de la increencia y su asociación a la inestabilidad, mediante el lenguaje simbólico del mar, tomado de Platón: R. MORTLEY, Connaissance religieuse, 201.

125 En este sentido hay que entender la fe no en sentido religioso sino gnoseológico, como convicción firme acerca de la verdad (cf. Strom., II, 15, 5). También, cf. H. A. Blair, Allegory, 264.

126 Con otras palabras: la aceptación de la verdad cristiana.

127 Strom., II, 49, 3. Para la distinción entre fe y gnosis, Clemente escribirá en Strom., VI, 131, 3, que la fe conserva intacta la tradición (la letra de la Escritura), mientras que la gnosis descubre la inteligencia de las Escrituras.

128 Cf. Strom., V, 5, 4.

129 Cf. Strom., V, 6, 1. 
dependientes de otros anteriores a ellos. Lo mismo sucede con la fe; no trata de probar la existencia de Dios, sino que Dios, primer principio y último, solo es accesible por la fe.

Por eso la certeza de la fe no reside en la lógica de la argumentación, sino en el objeto de dicha argumentación: la comprensión viene después de la fe; primero hay que creer, y como consecuencia lógica vendrá el juicio. Y hablamos de lógica en el sentido que lo entiende Clemente, es decir, como identificación con el Logos divino que se manifiesta hecho hombre en las Escrituras. También en este punto concreto la razón y la fe corren el mismo camino: tiene que haber cierta similitud entre la razón y el objeto razonable, lo mismo que entre la fe y lo creíble. El punto de discusión en Clemente es que Dios y la fe son correlativos. Ya en san Pablo la fe depende de Dios, pues «quien cree en Aquel que justifica al impío, se le cuenta su fe como justicia» ${ }^{130}$; se trata de ese Dios «que da la vida a los muertos y llama a las cosas que no existen como si existieran» ${ }^{131}$. Ese Dios es el primer principio y el último, que solo es accesible por la fe. Por tanto, concluye el Alejandrino, es razonable adherirse al primer principio mediante la fe, imposible de demostrar como todos los primeros principios, pero que recibe de Él, de Dios, juicios y demostraciones. De esta manera nos instruimos para conocer la Verdad, con mayúscula, y las otras partes verdaderas que de ella derivan. «En la vida gozan de una cierta superioridad los técnicos respecto a las personas comunes -escribe Clemente-, y consiguen obras muy superiores a las de las ideas comunes. Del mismo modo nosotros, sacando de las Escrituras pruebas perfectas sobre ellas mismas, obtenemos de la fe la fuerza de la demostración ${ }^{132}$.

Estas últimas palabras del maestro de Alejandría forman parte del capítulo dieciséis del libro séptimo de los Stromata, que Clemente dedica a contrarrestar las opiniones de los sofistas que interpretan mal la Sagrada Escritura. Para el Alejandrino la palabra de Dios es como el terreno bien preparado para que la fe germine, florezca y produzca los mejores frutos $^{133}$. Pero hay quienes la leen empleando la opinión o adaptan el

$130 \operatorname{Rm} 4,5$

$131 \operatorname{Rm} 4,17$.

132 Strom., VII, 95, 9-96, 1.

133 Desde esta perspectiva de la fe, los hechos históricos de la vida de Cristo adquieren un sentido subjetivo e interior; la fe se constituye en la clave de su muerte o de su vida en el alma del individuo. Clemente interpreta la fe en Cristo por su relación con la persona, más que con la historia objetiva de los acontecimientos. 
texto para justificar sus propias pasiones; aunque hay también quienes la leen empleando la fe, una confianza irrebatible, una demostración cierta. Estos últimos son los técnicos, que para aprender su profesión se adhieren a la escuela del Pedagogo perfecto, con el objetivo de ser formados a su semejanza. En este punto las diferencias que señala Clemente entre los maestros paganos y Cristo-Maestro son profundas: Demóstenes aprendió la retórica, Crisipo la dialéctica, pero Cristo nos forma según su propia naturaleza. De esta manera el Alejandrino manifiesta el deseo de equilibrio personal que posee el técnico cristiano en la certidumbre de su habilidad, pues es Dios mismo, el Inmutable, quien da al alma ese espíritu de percepción que no falla.

Pero fijémonos en la idea de la certidumbre de la fe, pues como hemos indicado no se apoya en la fuerza de sus argumentos, sino en el objeto de su demostración. El dinamismo existente entre fe y asentimiento proviene de su función como coherencia entre el alma y Dios, ya que ambos son los que aseguran el retorno a las fuentes, al primer y último principio. En sentido contrario, la separación de ambas, que es

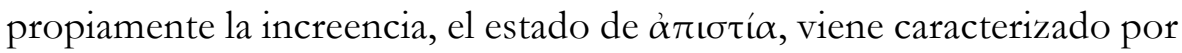
la debilidad y la impotencia. Por eso el ateo, dirá Clemente, tiene una vida privada de fuerza y fecundidad, ha perdido sus raíces. Sus palabras al respecto en el Protréptico son terminantes: «Ateísmo y superstición son cimas de ignorancia; hay que procurar permanecer fuera de ellos» ${ }^{134}$. Las palabras explicativas que añade el Alejandrino, por desacostumbradas, no parecen menos verdaderas: «El que invoca a muchos dioses falsos en lugar del único Dios verdadero, es lo mismo que el hijo de una prostituta demandando a muchos padres por desconocimiento del verdadero padre» ${ }^{135}$. Es decir, el creyente posee una vida que debe su vigor y fuerza a la Vida misma. La fe implica un deseo del conocimiento de la ciencia del auténtico Dios, y esta ciencia divina aporta al creyente el conocimiento de todo lo demás; de esta manera la fe adquiere un aspecto creador y poderoso.

Dios es fortaleza y su intermediario es la «palabra de su fuerza», que manifiesta la naturaleza del Padre en la vida terrena. Y la fe goza

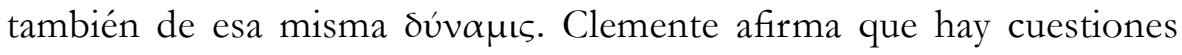
que son discutibles y lo serán siempre: nunca se sabrá el número de las

134 Protr., 25, 1.

135 Protr., 25, 2. 
estrellas, como ya hemos indicado. Pero existe también «un argumento irrefutable», que no puede ponerse en duda y que determina toda discusión. La comprensión de este argumento construye la fe, porque se impone; ante él no es posible ninguna pregunta. Esta certidumbre viene del hecho de que Dios se ha dirigido al hombre y le ayuda en sus investigaciones. Por otra parte, la autentificación de Dios, que no ofrece ninguna prueba de la verdad de su palabra, reside en que Él mismo es la Verdad. Dios no necesita el recurso a criterios externos distintos a Él mismo, como sucede por el contrario, con algunas cuestiones de la razón, que solicita la evidencia de los sentidos, según hemos visto. Por eso la fe-concluye nuestro Autor- «es más importante que la ciencia, y constituye su mismo criterio» ${ }^{136}$.

En el pensamiento de Clemente la fe goza de una posición privilegiada, como medio para captar la verdad; gracias a ella el hombre puede gozar de una claridad absoluta; es testigo valedero por sí mismo, elige lo mejor y no busca el bien, sino que lo realiza. Con la fe se puede contemplar la realidad inefable, y ofrece abundantemente la persuasión que proviene de la superioridad del Logos divino ${ }^{137}$. Así pues la fe no es debilidad ni ingenuidad necia, como decían algunos de sus colegas paganos, sino una capacidad humana muy razonable, más, incluso, que la propia razón del hombre.

Pero, ¿cuáles son las reglas o criterio por el que se puede comprobar la falsedad o autenticidad de la fe respecto al conocimiento de la verdad? Es la facultad de aceptar lo que es evidente en sí mismo lo que incentiva al espíritu su búsqueda sobre la verdad de las cosas. El Logos de Dios, en cuanto que es la palabra de Dios «no pronunciada», es la sabiduría misma, la bondad y el poder supremo, que también está presente de alguna manera en el espíritu humano. Pero es esa misma palabra de Dios proferida la que también viene en ayuda del hombre en las Sagradas Escrituras. Por eso la fe es segura, porque es Dios mismo quien se encuentra en la fuente del conocer; y porque el hombre creyente bebe en esas fuentes que saltan hasta la vida eterna por medio de su fe que le convierte también en fuente ${ }^{138}$. Así pues, quien tiene fe goza de una iluminación absoluta porque la fe le facilita esa claridad; descansa en el criterio inmutable de la

\footnotetext{
136 Strom., II, 15, 5.

137 Cf. Protr., 95, 3-96, 1.

138 Cf. Jn 4, 14.
} 
misma fe: «Por lo que a nosotros se refiere, hemos aprendido del Señor, mediante las Escrituras, que al hombre se le ha dado la facultad de elegir y de rechazar libremente ${ }^{139}$, apoyándose en la fe, como criterio inmutable; demostramos que el espíritu está pronto ${ }^{140}$, porque hemos elegido la vida y hemos creído a Dios mediante su voz» ${ }^{141}$.

En definitiva, el discernimiento o criterio de la autenticidad del conocimiento que aporta la fe es Dios mismo. Clemente lleva esta idea al plano de la razón, siguiendo a Aristóteles, relacionándolo con el concepto de que lo que es evidente en sí mismo se autentifica por sí mismo, sin necesidad de otros criterios externos. Así sucede, como hemos indicado más arriba, con la indemostrabilidad de los primeros principios, ya que son evidentes en sí mismos.

Podemos ya concluir que mientas la fe representa el comienzo del criterio mismo, la demostración constituye el cuerpo de enseñanza y de sabiduría que apuntala esa toma de conciencia inicial. La palabra de Dios encarnada en el Logos y representada en las Sagradas Escrituras, provoca la certidumbre, pues se trata de una demostración que no admite contradicción. "Quien cree en las divinas Escrituras ${ }^{142}$ hace sólido su criterio y de ahí que reciba como demostración irrefutable la voz de aquel que nos ha dado las Escrituras, de Dios; por ello, la fe no es algo que pueda apoyarse en la demostración ${ }^{143}$. Así, son bienaventurados los que han creído sin haber visto (Jn 20, 29) $)^{144}$.

139 Clemente expone ahora los argumentos sobre la fe, desde una perspectiva teológica. Se rechaza el naturalismo de los gnósticos. El hombre necesita ser salvado y, por ello, ser libre, poder elegir y optar: cf. S. Fernández Ardanaz, Génesis, 50; A. Zeoli, «Libero arbitrio, grazia e predestinazione nel pensiero di Clemente Alessandrino» en Humanitas 9 (1954) 853, n. 13.

140 Mt 26, 41; Mc 14, 38. Cf. V. Messana, «Lo Spirito Santo e l'accezione clementina di senso spirituale» en AugR 20 (1980) 489; J. Bernard, Die apologetische Methode, 160; L. F. Ladaria, El Espiritu en Clemente Alejandrino. Estudio teológico-antropológico, (Estudios 16; Madrid 1980) 147.

141 Strom., II, 12, 1.

${ }^{142}$ Los adjetivos «santas, sagradas y divinas» aplicados a las Escrituras demuestran en Clemente su autoridad: J. RuwET, «Clément d'Alexandrie. Canon des Écritures et Apocryphes» en Bibl 29 (1948) 85.

143 Con otras palabras: la fe precede a la demostración y se desarrolla en ella.

144 Strom., II, 9, 6. 


\section{Conclusión}

Hemos recorrido al trote el camino de la epistemología con los mejores compañeros de viaje: la fuerza de la razón y la certeza de la fe; y hemos sido guiados por un buen pedagogo, como es Clemente de Alejandría. Durante estos minutos hemos tratado de manifestar cómo la razón humana y la fe de la revelación pueden y deben llevarse bien, pues se necesitan mutuamente. Así, podemos concluir con el eco de las palabras de nuestro guía: «Si no es suficiente con expresar simplemente las opiniones, sino que es preciso comprobar lo que se dice, nosotros no aguardamos el testimonio proveniente de los hombres, sino que comprobamos el objeto de nuestra investigación con la palabra del Señor que ofrece una garantía superior a cualquier otra prueba, o mejor, que ella misma es la única prueba» ${ }^{145}$. En efecto, razón y fe se expresan con la misma importancia que cada una tiene conforme a su misma naturaleza, aunque en planos diversos por su misma esencia.

Es verdad que Clemente no ha desarrollado una verdadera teoría sobre las relaciones entre razón y fe, como las relaciones entre fe y razón que desarrollarán, de modo reflexivo y sistemático, otros autores posteriores del cristianismo, pero ha intuido el gran principio equilibrador entre ambas, es decir, Dios como único autor de la naturaleza y de la gracia. De una parte el Alejandrino no permite minusvalorar o desconocer la modesta contribución de la razón, pero tampoco enaltece tanto la doctrina revelada, como para declararla única certeza soberana en el camino que el hombre debe recorrer hacia su propia salvación eterna.

Clemente era pagano por su nacimiento y por su primera formación; pero era también auténticamente cristiano por el bautismo, por su segunda formación y por su fidelidad a la vocación cristiana. Esta doble circunstancia explica que en la formulación del fin y de los objetivos de la vida y de la educación se integren -no en paridad- elementos de ambas procedencias. Al preguntarse por el fin del hombre y de la vida, Clemente repasa explícitamente las opiniones varias de diversos filósofos. Especial consideración le merece Platón, porque entiende que su ideal encaja bien con el objetivo cristiano: asemejarse a Dios, que en esto consiste el bien supremo y fin último de hombre. También le merece particular estima el objetivo estoico de una vida conforme a la naturaleza y a la recta razón. Pero, naturalmente, la definición del fin último del hombre lo toma Cle-

145 Strom., VII, 95, 8. 
mente inequívocamente de las fuentes de la Revelación cristiana, con su perfil sobrenatural y transcendente, aunque en su formulación aparezcan elementos platónicos y estoicos.

Puesto que el hombre es, por símismo, radicalmente incapaz de alcanzar su fin último, Dios mismo viene en su ayuda; y así, la paideia cristiana esbozada por Clemente se convierte en una paideia divina ( $\dot{v} \vee$ X porque, en su esencia, no es otra cosa que un aspecto o dimensión de la obra salvadora que Dios realiza en favor de los hombres. En resumen, el objetivo que se propone el Alejandrino es dar a sus lectores un método de educación cristiana con todos los recursos divinos y humanos a su alcance y así poder participar de la vida incorruptible de Dios.

Resumen: Este artículo analiza la relación entre fe y razón en Clemente de Alejandría, quien, si bien no ha desarrollado una teoría sistemática sobre el particular, ha intuido el gran principio equilibrador: Dios mismo es autor de la naturaleza y la gracia. En este sentido, logra una eficaz síntesis de ambas: no permite minusvalorar o desconocer la modesta contribución de la razón, sin enaltecer tampoco la doctrina revelada, al punto de declararla única certeza soberana en el camino que el hombre debe recorrer hacia su propia salvación eterna. El artículo está complementado con un estudio de los antecedentes histórico-culturales y biográficos que permite comprender adecuadamente el contexto del pensamiento de Clemente.

Palabras clave: Clemente de Alejandría; fe y razón; epistemología.

Abstract: This article analyzes the relationship between faith and reason in Clement of Alexandria, who, although he did not develop a systematic theory on the matter, sensed the great balance principle: God Himself is the author of nature and grace. Thus he achieves an effective synthesis of both: he does not allow the modest contribution of reason to be underestimated or ignored, but does not exalt revealed doctrine to the point of declaring it the only sovereign certainty on the road that man must take towards his own eternal salvation. This article is complemented by a study of historical-cultural and biographical background information to properly understand the context of Clement's thought.

Key words: Clement of Alexandria; faith and reason; epistemology. 